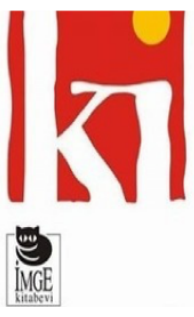

Kültür ve Iletişim

culture\&communication

Yıl: 24 Sayl: 47 (Year: 24 Issue: 47)

Mart-2021-Eylül 2021 (March 2021-September 2021)

E-ISSN: 2149-9098

2021, 24(1): 286-323

DOI: $10.18691 /$ kulturveiletisim. 783964

${ }^{\star *}$ Araştırma Makalesi ${ }^{\star *}$

\title{
Toplumsal Cinsiyet Eşitliği ve Üniversite Öğrencilerinin Tutumları*
}

\author{
Aynur Örnek ${ }^{\star \star}$
}

Öz

Toplumsal cinsiyet, kadınlara ve erkeklere toplumsal olarak uygun görülen rolleri ve sorumlulukları ifade etmektedir. Bir başka deyişle, toplumun ya da kültürün cinsiyetle ilişkili olarak bireyden beklediği davranışlardır. Geleneksel toplumlarda kadınların erkeklere göre ikinci konumda kalması toplumsal cinsiyet kavramını tartışmalı hale getirmekte, toplumsal yaşamın birçok alanında erkeğe kadından daha fazla değer veren eşitsizlik durumu yaşanmaktadır. Söz konusu eşitsizlik özellikle, çalışma yaşamı, aile içi yaşam, eğitim, siyaset ve sağlık hizmetlerinden yararlanma gibi alanlarda kendini göstermektedir. Toplumsal cinsiyet eşitliğinin oluşturulabilmesi için her yaş ve cinsiyetteki bireyin, özellikle gençlerin bilinçlendirilmeleri ve eşitlikçi bakış açısı geliştirmeleri sağlanmalıdır. Bu araştırmanın amacı da üniversite öğrencilerinin toplumsal cinsiyet eşitliğine ilişkin tutumlarını tespit etmektir. Araştırmanın evrenini Aydın Adnan Menderes Üniversitesi İletişim Fakültesi öğrencileri oluşturmaktadır. Fakültenin 2017-2018 eğitim öğretim yılında toplam öğrenci sayısı 381'dir. Araştırmanın örneklemi ise çalışmaya katılmayı kabul eden 277 öğrenciden oluşmaktadır. Katıımcı öğrencilerin yüzde 44'ü kadın, yüzde 56'sı erkektir. Öğrencilerin 105'i 1.sınıf, 81'i 2.sınıf, 69'u 3.sınıf ve 22'i 4.sınıfta bulunmaktadır. Araştırmaya katılan öğrencilerin yaş ortalaması ise 20.82 'dir. Araştırmada veri toplama aracı olarak "Toplumsal Cinsiyet Eşitliği Tutum Ölçeği" kullanıımıştır. Araştırma sonucunda öğrencilerin "orta düzeyde" cinsiyet eşitliği tutumuna sahip oldukları tespit edilmiştir.

Anahtar Sözcükler: Toplumsal cinsiyet eşitliği, üniversite öğrencisi, tutum.

\footnotetext{
* Geliş tarihi: 22/08/2020 . Kabul tarihi: 23/01/2021

** Aydın Adnan Menderes Üniversitesi İletişim Fakültesi, Radyo Televizyon ve Sinema Bölümü. Orcid no: 0000-0002-3714-1187, aynuro@adu.edu.tr
} 


\title{
${ }^{* *}$ Research Article ${ }^{\star *}$ \\ Gender Equality and the Attitudes of the University Students*
}

Aynur Örnek ${ }^{\star *}$

\begin{abstract}
Gender refers to the roles and responsibilities that are considered socially appropriate for women and men. In other words, they are the behaviors that society or culture expects from the individual in relation to gender. In traditional societies, the fact that women remain in the second position compared to men makes the concept of gender controversial, and there is an inequality that values men more than women in many areas of social life. This inequality manifest itself particularly in working life, family life, education, politics and benefit from the health services. In order to create gender equality, individuals of all ages and genders, especially young people, should be made aware of and develop an egalitarian perspective. This research aims to determine university students' attitudes towards gender equality. The population of research consists of students studying at the Faculty of Communication of Aydın Adnan Menderes University. The total number of students at the faculty is 381 during the 20172018 academic year. The sample of the research consists of 277 students who agreed to participate in the study. 44 of the participating students are females and 56 are males. 105 of the students are in the $1^{\text {st }}$ grade, 81 are in the $2^{\text {nd }}$ grade, 69 are in the $3^{\text {rd }}$ grade and 22 are in the $4^{\text {th }}$ grade. The mean age of the students participating in the research is 20.82 . "Gender Equality Attitude Scale" was used as a data collection tool in the study. As a result of the research, it was determined that the students have a "moderate" gender equality attitude.
\end{abstract}

Keywords: Gender equality, university student, attitude.

* Received: 22/08/2020. Accepted: 23/01/2021

** Aydın Adnan Menderes University Faculty of Communication, Radio Television and Cinema Department.

Orcid no: 0000-0002-3714-1187, aynuro@adu.edu.tr 


\section{Toplumsal Cinsiyet Eşitliği ve Üniversite Öğrencilerinin Tutumları}

\section{Giriş}

Gençlik çağı birçok genç için yaşamlarının geri kalan bölümüne ilişkin önemli bazı kararlar alma, tercihler yapma dönemi olarak kabul edilmektedir (Jersild,1978: 14). Gencin yetişkin toplumuna girmesi, sosyal ve ekonomik yönleri ile benliğinin gelişmesi açısından önemli bir olaydır (Şemin,1973: 6). Bu geçiş dönemi, gençlerin toplumsal cinsiyet bakış açılarını da etkilemektedir. Üniversite öğrencileri ise genç nüfus içinde özel bir yere sahiptir. Öğrencilerin toplumsal cinsiyet eşitsizliğine ilişkin tutumlarının değerlendirilmesi sürdürülebilir bir kalkınma ve eşitlikçi düşünceye sahip nesillere ulaşma açısından büyük önem taşımaktadır (Pınar vd., 2008: 49).

Cinsiyet, bireylerin doğuştan sahip oldukları genetik, fizyolojik ve biyolojik özellikler olarak tanımlanmaktadır. Günümüzde ise cinsiyet ya da biyolojik cinsiyet kavramları yerine atanmış cinsiyet kavramı tercih edilmektedir. Kaos GL Derneği'nin yayımladığı Çeviri Sözlüğü'nde atanmış cinsiyet kavramı şu şekilde açıklanmaktadır: "Doğumda veya henüz rahimdeyken bebeğin dış genital özelliklerine atfedilen beden cinsi üzerinden inşa edilmiş varsayımlarla kişilerin sınıflandırıldığı ya da kişilere atanan cinsiyet. Genellikle 'doğumda erkek olarak atanmış' ya da 'doğumda kadın olarak atanmış' şeklinde kullanılır” (Kaos GL, 2020). Toplumsal cinsiyet ise atanmış cinsiyetle uyumlu olduğu varsayımıyla, sosyal ve kültürel açıdan iki cinsiyete ilişkin normları ve rolleri açıklamak için kullanılır. Kadına uygun görülen toplumsal cinsiyet rolleri genellikle kadına atfedilen duygusallık ve bağımlılık; erkeğe uygun görülen toplumsal cinsiyet rolleri ise erkeğe atfedilen önderlik ve özgürlük özellikleriyle açıklanmaktadır (Zara ve Özdemir, 2013: 3). Bununla ilişkili olarak birçok kültürde kadınlara uygun görülen roller çocuk bakmak, yemek yapmak ve çamaşır yıkamak iken; erkeklere uygun görülenler genellikle iş sahibi olmak, maddi gelir sağlamak ve araba kullanmaktır (Morris, 2002: 619).

İnsanların kadınlık ve erkeklik rollerini toplumsallaşma süreci içinde öğrendikleri araştırmalar tarafından gösterilmiştir. Bu süreç içinde aile, okul, kitle iletişim araçları gibi unsurlar geleneksel cinsiyet rollerinin öğrenilmesinde önemli etkileri olan kurumlar 
olarak kabul edilmektedir. Toplumsallaşma sürecinde kadınlara ve erkekler farklı rollerin uygun görülmesi ve bu roller çerçevesinde gelişen beklentiler, toplumsal cinsiyet eşitsizliğine neden olmaktadır. Bu araştırmada da toplumsal cinsiyet kavramı ile ülkemizde kadının durumu ve üniversite öğrencilerinin toplumsal cinsiyet eşitliği konusundaki görüşleri üzerinde durulacaktır. Araştırma, Aydın Adnan Menderes Üniversitesi İletişim Fakültesi'nde lisans öğrenimini sürdüren öğrencilerin toplumsal cinsiyet rollerine ilişkin görüşlerini belirleyerek konu ile ilişkili öneriler geliştirmek amacıyla gerçekleştirilmiştir. Mezuniyetleri sonrası medya sektöründe çalışacakları öngörülen iletişim fakültesi öğrencilerinin, hazırlayacakları medya metinlerinde kadın hakları, toplumsal cinsiyet eşitliği, kadına yönelik şiddet gibi konulardaki düşünceleri önemlidir. Bu çerçevede öğrencilerin toplumsal cinsiyet rollerine ilişkin görüşlerinin hangi yönde (eşitlikçi ya da geleneksel) olduğu, cinsiyetler arasında görüş farkının olup olmadığı araştırılacaktır.

Araştırmada mevcut durumu araştırmak ve belirlemek için betimsel tarama yöntemi tercih edilmiştir. Tarama modelleri geçmişte ya da günümüzde mevcut olan bir durumu olduğu gibi betimlemeyi amaçlayan araştırma yöntemleridir (Karasar,1995: 77). Araştırmanın verileri anket formu aracılığı ile toplanmıştır. Formun ilk bölümünde öğrencilerin tanımlayıcı bilgilerini içeren sorular, ikinci bölümde ise öğrencilerin cinsiyet rollerine ilişkin görüşlerini belirlemeye yönelik 5'li likert tipi ölçek bulunmaktadır. Araştırmada kullanılan ve 15 sorudan oluşan "Toplumsal Cinsiyet Eşitliği Tutum Ölçeği”, Aile lçi Şiddetle Mücadele Projesi / Sağlık Çalışanları Eğitici El Kitabı'ndan alınmıştır (Aile ve Sosyal Politikalar Bakanlığı, 2016: 317). Toplumsal cinsiyet eşitliği tutum ölçeğinden öğrencilerin tutum puanlarını incelemek için gereken istatistiksel testin belirlenmesi amacıyla öncelikle öğrencilerin tutum puanlarının dağılımının normalliği test edilmiştir. Bu amaçla Shapiro-Wilk normallik testi uygulanmış ve normallik testiyle incelenen tutum puanlarına ilişkin bulgular değerlendirilmiştir. Kullanılan istatistiksel analizler arasında ortalama, medyan, standart sapma, çarpıklık katsayısı, basıklık katsayısı bulunmaktadır. Araştırmada ayrıca ölçek maddelerine verilen yanıtların yüzde dağılımları hesaplanmıştır. Araştırma sonucunda öğrencilerin ölçekten elde ettiği en az puan 15, en yüksek puan 75 olarak bulunmuştur. Uygulanan ölçeğin puan ortalaması ise 36.57 'dir. Bu puan sonucunda öğrencilerin orta düzeyde cinsiyet eşitliği tutumuna sahip oldukları söylenebilir. 


\section{Toplumsal Cinsiyet Olgusunun Tanımı ve Özellikleri}

Toplumsal cinsiyet toplumun kadına ve erkeğe uygun bulduğu rolleri, görev ve sorumlulukları açıklamaktadır. Toplumsal cinsiyet, sosyal olarak belirlenmekte ve kültürden kültüre farklııık göstermektedir. Biyolojik farklııklardan dolayı değil kadın ve erkek olarak toplumun bizi nasıl gördüğü, nasıl algıladığı, nasıl düşündüğü ve nasıl davranmamızı beklediği ile ilgili bir kavramdır (Akın, 2007: 2).

Feminist tarihçiler toplumsal cinsiyeti açıklamak için farklı yaklaşımlardan yararlanmışlardır. Bu yaklaşımlardan ilki, ataerkinin kökenlerini açıklamakta, ikincisi de kendini Marksist gelenek içinde konumlandırmaktadır. "Fransız post-yapısalcılar ile Anglo-Amerikan nesne-ilişkileri kuramcıları arasında bölünmüş olan üçüncü yaklaşım ise öznenin toplumsal olarak cinsiyetlendirilmiş kimliğinin üretimini ve tekrar üretimini açıklamak için psikanaliz ekollerinden yararlanmışlardır” (Scott, 2010: 117).

Queer teorinin kurucularından biri olan Judith Butler ise Cinsiyet Belası: Feminizm ve Kimliğin Altüst Edilmesi (2019) isimli kitabında feminist kuram içinde yer alan heteroseksüel varsayımı, bir başka deyişle feminist hareketin kimlikleri kadın ve erkek olarak sabitleştirmesini ve onların ortak özellikler etrafında bir araya getirilerek genellemesini kabul etmemektedir. Butler, sabit kimliklere karşı akışkan kimlikler önermekte ve yeniden deneyimlenecek kimlikler için performatif (edimsel) kavramına başvurmaktadır (Ecevit, 2011: 24). Butler'in geliştirdiği performatif toplumsal cinsiyet kavramı, kadınlık ve erkeklik olmak üzere yalnızca iki farklı toplumsal cinsiyet yerine pek çok toplumsal cinsiyetin varlığını kapsamaktadır. Heteronormativiteyi reddeden Butler, normları saptırmayı önerir. Bu çerçevede "queer"in kendisi yeni bir norm ya da kimlik değil, akışkan ve belirsiz bir kimlik(sizlik) durumudur (Sever, 2014). Ecevit'in de belirttiği gibi queer hareketi öncelikle heteroseksüel anlayışın üzerinde durduğu toplumsal cinsiyet yapısında, öteki olarak kabul edilen kişilerin eşit haklara sahip olmak için verdikleri mücadeleyi vurgulamak için gündeme gelmiştir. Söz konusu mücadele, homofobiye karşı olan düşünceye ve LGBT'lere (lezbiyen, gay, biseksüel ve transseksüel) ayrımcı yaklaşımlar uygulayan yönetimlere yönelik gerçekleşmiştir (Ecevit, 2011: 24).

Butler, toplumsal cinsiyet alanındaki argümanlarını kadın-erkek ikiliği üzerinden oluşturan feminist düşünceyi eleştirerek, feminizmin ataerkinin yaptığını başka bir 
biçimde gerçekleştirdiğini belirtmektedir. Bir başka deyişle feminizmin çerçevelenmiş bir kadın tanımıyla kadınlığı sınırlandırdığını düşünür. Cinsel farkı savunan feminizm, zorunlu olarak heteroseksist varsayımlara dayanmaktadır oysa performatif olarak kavrandığında heteroseksizme karşı başka bir siyaset mümkün olabilecektir. Butler'e göre "Cinsiyet Belası'nın olumlu bir normatif görevi varsa o da bu meşruiyetin yanlış, gerçekdışı ve idrak edilemez addedilmiş bedenleri de kapsayacak şekilde genişletilmesinde ısrar etmektir” (Butler, 2019: 32). Bu çalışmada ise kullanılan ölçek gereği queer kurama ilişkin literatürden yararlanılmamış, çalışma toplumsal cinsiyet kavramı çerçevesinde gerçekleştirilmiştir. Bu durum çalışmanın bir sınırıılığıdır.

Toplumsal cinsiyet kavramı, kadın ve erkek arasında sosyal, kültürel, ekonomik ve siyasi alanlarda yaşanan farklılıkları ifade etmektedir. Söz konusu farklılıklar toplum ya da egemen ideoloji tarafından desteklenmekte, aile ve devlet gibi toplumsal kurumlar bireye kadın ve erkekliğe ilişkin kalıp yargıları dayatmaktadır. Dünyanın hemen hemen her ülkesinde kadınlar toplumun onlara uygun bulduğu roller nedeniyle sağlık, eğitim ve ekonomik kaynaklardan eşit oranda yararlanamamaktadır. Kadının yaşamını olumsuz yönde etkileyen toplumsal rol kalıpları aynı zamanda toplumsal cinsiyet eşitsizliğine neden olmaktadır (Pınar vd., 2008: 48). Sanayi toplumlarında kadınlar genellikle ev içinde ya da hizmet sektöründe çalışırken, erkekler ev dışında, kadınlara göre daha iyi işlerde ve daha yüksek ücret karşılığında çalışmaktır (Marshall, 1999: 101).

Kapitalist toplumlarda toplumsal cinsiyet eşitliği yerine, kültürün cinsiyetçi yapılanması sonucunda kadının ev içinde çalışmasını uygun bulan, ev içindeki emeği ekonomik açıdan karşılıksız bırakan, siyasi ve ekonomi alanlarını erkeklere uygun gören yapılanmadan söz etmek mümkündür. Cinsiyete göre iş bölümü olarak değerlendirilen bu yapı, her iki cinsiyetin gerçekleştirdiği işleri açıklarken aynı zamanda iktidar ilişkilerini de tanımlamaktadır. Söz konusu iş bölümü kadına evin içini gösterirken, bu alan içinde kimin hangi ev işlerini gerçekleştireceğini de göstermektedir. İş bölümü, kadın ve erkeğe farklı davranışları ve yetenekleri uygun gören faaliyetleri ve temsilleri içeren geniş bir alanı kapsamaktadır (Agarwal, 1994). Ataerkil yapı, kadınlara arka planda kalmalarını ve erkeği destekleyici rolleri kabul etmeleri gerektiğini söylemektedir. Toplum, erkeklere her türlü zorluk karşısında mücadele eden, önderlik özelliği bulunan, kuvvetli ve çalışkan gibi özellikleri yüklerken 
kadınların şefkatli ve duygusal olduğu kalıp yargısı üzerinden, erkeklere yardım etme, evine ve çocuklarına bakma rollerini uygun görmektedir. Ne yazık ki erkeklere uygun görülen bu nitelikler, sosyal yaşamda ve aile içinde erkeklerin sahip olduklarını düşündükleri güçlerini kadınlara yönelik kullanmalarına neden olmaktadır (Cangöz, 2013: 46-47).

\section{Türkiye'de Toplumsal Cinsiyet Eşitsizliği}

Küresel Toplumsal Cinsiyet Uçurumu Raporu kadınlar ile erkekler arasında dört kategoride eşitlik farkını incelemektedir. Bunlar, temel olarak eşit koşullarda işgücüne katılma, eğitim olanaklarından ve sağlık hizmetlerinden yararlanma ile siyasi katılım olarak sayılabilir. Dünya Ekonomik Forumu'nun (WEF) 2018 yılına ait Küresel Toplumsal Cinsiyet Uçurumu Raporu, Türkiye'nin 149 ülke içinde cinsiyet eşitliğinde 130. sırada yer aldığını göstermektedir. 2006 yılına ait WEF raporunda Türkiye 105. sırada yer alırken, 2018 yılında 130. sıraya gerilemiştir. 2018 raporunda olumlu yönde ilerleyen tek alan kadınların yönetim kademesindeki yüzde 34 oranındaki artışıdır (Word Economic Forum, 2018). WEF'in 2020 raporunda ise Türkiye 153 ülke arasında cinsiyet eşitliği sıralamasında 130. sırada yer almaktadır. Rapora göre Türkiye, kadınların işgücüne eşit oranlarda katılımı sıralamasında 136., eğitimde 113., sağlık hizmetlerinden yararlanmada 64. ve siyasi alanda 109. basamaktadır (Word Economic Forum, 2020).

Kadına yönelik şiddet de toplumda kabul edilen kadınlık ve erkeklik normları ile ilişkilendirildiğinde toplumsal cinsiyet ayrımcılığının bir sonucu olarak kabul edilmektedir. Zehra Gönül Balkır, kadına yönelik şiddetin kökeninde yer alan sosyokültürel faktörleri beş grup altında toplamaktadır. Bunlar; toplumun ataerkil yapıya verdiği önem; otoriteyi önemseyen gelenek ve kültürün kabul edilmesi; kadın ve erkeğin aynı mekanda bulunmaması gerektiğini düşünen inançlar; değerler; yargılar ve geniş aile; hemşericilik gibi ilişkilerin yaygınlığı sonucunda birey üzerinde oluşan toplumsal baskılar olarak sıralanabilir (Balkır, 2012: 71). Türkiye'de son on yıl içinde erkeklerin katlettiği kadın sayısındaki artışa baktığımızda şiddetin boyutlarının ne kadar büyük olduğunu görebiliriz. Şiddetten Ölen Kadınlar İçin Dijital Anıt’ın (2019) verilerine göre Türkiye'de 2008 yılında 66, 2018 yılında 396 kadın, erkeklerin uyguladığı şiddet sonucunda yaşamını yitirmiştir. İlki 2008 yılında, ikincisi ise 2014 
yılında gerçekleştirilen Türkiye'de Kadına Yönelik Aile Içi Şiddet Araştırması'na ait veriler de Türkiye'de kadına yönelik şiddetin boyutlarını gözler önüne sermektedir. 2014 yılına ait araştırmada kadınların eşleri ya da ayrıldıkları eşleri tarafından fiziksel şiddete uğrama oranı yüzde 36, 2008 araştırmasında ise yüzde 39 olarak tespit edilmiştir. 2014 ve 2008 araştırmalarının her ikisinde de yaşamlarında duygusal şiddetle karşılaşan kadınların oranı yüzde 44 olarak bulunmuştur. 2008 araştırmasında şehirlerde fiziksel şiddet yüzde 38, kırsal kesimde yüzde 43 oranındadır. 2014 araştırmasında fiziksel şiddetle karşılaşan eğitim almamış kadınlar yüzde 43, üniversite eğitimi alanlar yüzde 21 olarak tespit edilmiştir. 2008 yılına ait araştırmada ise eğitim almamış kadınların şiddetle karşılaşma oranı yüzde 55,7 olarak belirlenmiştir. Bu veriler eğitimin kadınların yaşamlarındaki önemi açık bir şekilde göz önüne sermektedir (Yüksel-Kaptanoğlu vd., 2015).

Toplumsal yaşamda kadınların baş etmek zorunda kaldığı en önemli sorunlardan birisi de hiç kuşkusuz eğitim alanındaki eşitsizliklerdir. Türkiye İstatistik Kurumu (TÜIK) tarafından yayımlanan “İstatistiklerle Kadın 2018” verilerine göre, 2017 yılında 25 ve üzeri yaşta olan ve en az bir eğitim düzeyinden mezun bireylerin toplam nüfus içindeki oranı yüzde 89.5'tir. Bu oran erkeklerde yüzde 95.5, kadınlarda yüzde 83.6 olarak tespit edilmiştir. TÜíK verilerine göre okuryazar olmayan bireylerin toplam nüfus içindeki oranı ise yüzde 4.8'dir. Erkeklerin yüzde 1.5, kadınların yüzde 8.0'i okuryazar değildir (Türkiye İstatistik Kurumu, 2019a). Veriler, kadınların eğitim olanaklarına ulaşmada erkeklerin gerisinde kaldıklarını göstermektedir. Bu durum kadınların çalışma yaşamına katılımını da olumsuz yönde etkilemektedir.

TÜIKK verilerine göre Ağustos 2018/Ağustos 2019 döneminde 15 ve üzeri yaştaki bireylerin işgücüne katılma oranı, toplamda yüzde 54.3, erkeklerde yüzde 74.1 kadınlarda ise yüzde 34.9 olarak açıklanmıştır. İstihdam oranı ise toplamda yüzde 48.3 iken, erkeklerde yüzde 67.3, kadınlarda yüzde 29.7'dir. 2019 yılında ise işgücüne katılma oranı toplamda 0.4 puanlık azalış ile yüzde 53.9, erkeklerde 0.9 puan azalış ile yüzde 73.2, kadınlarda 0.1 puanlık artış ile yüzde 35.0 olarak tespit edilmiştir (Türkiye İstatistik Kurumu, 2019b). TÜIK verilerine göre 2019 yılı Temmuz döneminde kadın ve erkeklerin çalışma durumları Tablo 1'de yer almaktadır. 


\begin{tabular}{l|rrr}
\hline \multicolumn{1}{c}{$\begin{array}{c}\text { Iş̧teki } \\
\text { Durum }\end{array}$} & Toplam & Kadın & Erkek \\
\hline Ücretli ya da Yevmiyeli & 19.217 & 5.841 & 13.337 \\
İşveren & 1.280 & 126 & 1.154 \\
Kendi Hesabına & 4.739 & 794 & 3.945 \\
Ücretsiz Aile İşçisi & 3.280 & 2.286 & 994 \\
\hline
\end{tabular}

Tablo 1: Cinsiyetlerin işteki durumu Temmuz 2019 / bin kişi (Türkiye İstatistik Kurumu, 2019c.)

Tabloda da görüldüğü gibi kadının erkeğe göre ön sırada olduğu tek alan ücretsiz aile iş̧̧iliğidir. Ülkemizde kadın iş gücüne yönelik beklentilerde geleneksel bakış açısının devam ettiğini belirten Türkel Minibaş bu durumu toplumun olduğu kadar kadının da kendisini tanımlamada kullandığı önceliklerin etkisine bağlamaktadır. Minibaş’a göre hem toplumun hem de kadının kendisine uygun bulduğu öncelikli rol "eş anne" lik ve devamında ev kadınlığıdır. Bu öncelik devam ettiği müddetçe kadının iş gücü olarak "ucuz emek", "yardımcı aile işçisi" ve benzer şekilde tanımlanması devam edecektir (1998: 331).

"Aile Yapısı Araştırması 2016" sonuçlarına göre Türkiye'de kadınların yemek pişirme, bulaşık ve çamaşır yıkama, ev temizliği ve ütü yapmak gibi sürekliliği olan ev işlerini yaptığı, erkeklerin ise tamir, boya badana, fatura yatırma gibi başlangıcı ve sonu belli olan işleri yaptığı tespit edilmiştir. Yemek yapma işini yüzde 91.2 oranında kadınlar yaparken, erkeklerin yemek yapma oranı yüzde 8.8'dir (Türkiye İstatistik Kurumu, 2017). Birleşik Metal i̇ş Sendikası Araştırma Merkezi'nin (BiSAM) gerçekleştirdiği "Elektrik Elektronik Sektöründe Çalışma Koşulları ve Toplumsal Cinsiyet Rollerinin Kadın Iş̧̧iler Üzerindeki Etkileri: İşyeri Vaka Analizi” adı çalışmada ise kadınların yarısından fazlasının ev işlerini yalnızca kendilerinin yaptığı tespit edilirken, evli kadınların yalnızca yüzde 13'ü ev işlerini eşleriyle paylaştıklarını belirtilmiştir (Cumhuriyet, 2020).

Ev işlerinin büyük bir bölümünü üstlenen kadınlar ne yazık ki çalışma yaşamında erkeklere göre daha alt statüdeki işlerde çalışmak zorunda kalmaktadır. Hane halkı işgücü araştırması sonuçlarına göre, şirketlerde üst düzey ve orta kademe yönetici konumundaki kadın oranı 2012 yılında yüzde 14.4 iken 2017 yılında yüzde 17.3 olarak tespit edilmiştir (Türkiye İstatistik Kurumu, 2018). Aile Çalışma ve Sosyal Hizmetler Bakanlığı Çalışma Genel Müdürlüğü’nün kamu kurum ve kuruluşlarında çalışan personele ilişkin açıkladığı veriler ise şöyledir: 


\begin{tabular}{l|ccc}
\hline \multicolumn{1}{c}{ Ünvanlar $^{*}$} & Kadın Çalışan & Toplam Üst Düzey Çalışan & Oran Yüzde \\
\hline Vali & 2 & 81 & 2.47 \\
Genel Müdür & 14 & 143 & 9.79 \\
Genel Müdür Yardımcısı & 34 & 299 & 11.37 \\
Başkan & 1 & 33 & 14.29 \\
Başkan Yardımcısı & 7 & 119 & 3.03 \\
Daire Başkanı & 420 & 2.522 & 16.65 \\
Kaymakam*** & 23 & 830 & 2.77 \\
Bölge Müdürü & 11 & 179 & 6.15 \\
Bölge Müdür Yardımcısı & 18 & 479 & 3.76 \\
Toplam & 534 & 4.690 & 11.38 \\
\hline
\end{tabular}

Tablo 2: Unvanlara göre çalışan kişi sayısı (Aile Çalışma ve Sosyal Hizmetler Bakanlığı Kadının Statüsü Genel Müdürlüğü, 2020.)

*657 sayılı Devlet Memurlar Kanununda üst düzey unvan tanımı yapılmadığı için yönetici pozisyonundaki bazı ünvanlar gruplandırılarak verilmiştir.

*Gruplandırmada büyükşehir belediyeleri, kuruluşları ve belediyenin üst düzey ünvanları yer almamaktadır.

***içişleri Bakanlığı Ocak 2020 verileridir.

Deniz Kandiyoti'ye (1997: 52) göre ev dışında çalışan kadınların hem iş hem de ev sorumluluklarını birlikte yürütmeleri sonucunda yaşadıkları sıkıntılar, yeni rol taleplerinden korunmak isteyen erkeklere az oranda yansıtılmaktadır. Söz konusu koruma işlevini, değişimin etkilerini evli çiftten uzak tutarak tampon konumunda bulunan başka kadınlar sağlamaktadır. Bu kadınlar genellikle hizmetçi, yoksul akraba ya da annelerden oluşmaktadır. Bu çerçevede toplumsal yapıdan desteklenen erkeğe ait rol, değişimden sınırlı oranda etkilenerek varlığını sürdürmektedir.

Kadınların eğitim ve çalışma yaşamında karşılaştığı eşitsizlikler siyasi alanda da karşısına çıkmaktadır. Aile Çalışma ve Sosyal Hizmetler Bakanlığı bünyesinde Kadının Statüsü Genel Müdürlüğü’nün 2020 yılında yayınladığı Türkiye'de Kadın çalışması 1935-2018 yılları arasında cinsiyete göre milletvekili sayısı ve meclisteki temsil oranındaki eşitsiz dağılımı göstermektedir. 1935 yılında toplam 395 olan milletvekilinin yalnızca 18’i kadındır. Dolayısıyla erkeklerin temsil oranı yüzde 95.5, kadınların temsil oranı ise yüzde 4.5'tir. 2018 yılında ise 600 milletvekilinin 104'ü kadındır. Temsil oranı erkeklerde yüzde 82.7, kadınlarda yüzde 17.45'dir (Aile, Çalışma ve Sosyal Hizmetler Bakanlığı Kadının Statüsü Genel Müdürlüğü, 2020).

Toplumsal cinsiyet ayrımcılığı nedeniyle kadınlar eğitim, çalışma yaşamı ve siyasi katılımda karşılaştıkları sorunlar dışında kendilerine sunulan sağlık hizmetlerinden de yeterince yararlanamamaktadır. Özellikle okuryazar olmayan 
kadınların istediklerinden daha fazla çocuk sahibi olmaları sağlık sorunları yaşamalarına neden olmaktadır. Bununla birlikte kadınların eğitim düzeyi yükseldikçe sağlık hizmetlerden daha fazla yararlandığı bilinmektedir (Akın, 2007: 5). Ayrıca ülkemizde çocuk yaşta yapılan evlilikler kadınların sağlığını olumsuz yönde etkileyen önemli sorunlardan birisidir. Ergen doğum oranları ve anne ölümleri önemli sorunlar arasında yer almaktadır. BiSAM'ın gerçekleştirdiği çalışmada ise toplumsal cinsiyet rolleri ile kadın işçilerin yaşadığı ağrılar arasında ilişki olduğu saptanmıştır. Çalışmada "evli kadın işçilerde kas iskelet sorunu yaşayanların oranı yüzde 39 iken, evli olmayanlarda bu oranın yüzde 14'e düştüğü" gözlenmiştir (Cumhuriyet, 2020).

\section{Toplumsal Cinsiyet Tutumu}

1981 yılından itibaren farklı ülkelerde yaşayan bireylerin değerleri ve inançlarını saptamaya yönelik gerçekleştirilen Dünya Değerler Araştırması (World Values Survey) beş yıllık zaman dilimlerinde çeşitli ülkelerde yaşayan kişilerin değerlerini, inançlarını ölçmekte, böylelikle söz konusu toplumların hoşgörü ve demokrasi seviyeleri belirlenmektedir. Medeni Kanun, ailede erkeğin reisliğine son vermesine rağmen 2012 Türkiye Değerler Araştırması'nın sonuçlarına göre "Bizim toplumumuzda ailenin reisi erkek olmalıdır” düşüncesine katılanları oranı toplamda yüzde 76 olarak tespit edilmiştir. Bu oran erkeklerde yüzde 81, kadınlarda yüzde 71'dir (Esmer, 2012).

Dünya Değerler Araştırması 2010-2014 Raporu'nda ise ülkemize ait bulgulardan bazıları şunlardır; Türkiye toplumunda aile yüksek düzeyde (yüzde 95.4) önem verilen bir kurum olarak kabul edilmektedir. İş konusu yüzde 49.6’lık oranla “çok önemli” bulunmaktadır. Ayrıca toplumda ataerkil ve maço özellikler baskın görünmektedir. Örneğin toplumun önemli bir bölümü (yüzde 47.1) için kadınların eşlerinden daha yüksek maaş alması problem olarak görülmektedir. İşsizlik oranlarının yükseldiği durumlarda iş için erkeklerin önceliğinin olmasını düşünenler yüzde 59.4, kadın işe gittiğinde çocukların üzüleceğini düşünenler ise yüzde 65.9'dur. Ayrıca siyaseti erkeklerin alanı olarak görenler yüzde 68, iş hayatında erkeklerin daha iyi performans gösterdiğine inananlar ise yüzde 64.1 olarak tespit edilmiştir (Örmeci, 2016).

Çalışmalar toplumsal cinsiyete yönelik tutumların oluşmasında aile ve sosyal çevrenin önemli rol oynadığını göstermektedir. Öncelikle anne-baba, okul, arkadaşlar, 
kitaplar, kitle iletişim araçları gibi çeşitli unsurlar çocuğun davranış ve kuralları içselleştirmesine katkı sağlamaktadır (Connell,1998; Driscoll ve Nagel, 2008; Meece ve Daniels, 2008'den akt., Yağan Güder ve Yıldız, 2016: 425). Pilcher'a (2017: 109) göre toplumsallaşma kuramları, cinsiyet eşitsizliğini toplumsal faktörlere vurgu yaparak açıklamaktadır. Bu çerçevede kadın ve erkek biçiminde iki rolden söz etmek mümkündür. Kadınlar ve erkekler, onlara uygun olan rolü bebeklik ve çocukluğun ilk dönemlerinde toplumsallaşma yolu ile öğrenmektedir. Çocuklara dişi ya da erkek rollerine uygun davranmaları, bu rollere iliştirilmiş beklentiler ve normlar yerine getirilerek öğretilmektedir. Toplumsallaşma yolu ile öğrenilen bu roller, cinsiyetçi yaklaşım içinde bulunmayan yöntemlerle değiştirildiği takdirde cinsiyet eşitsizliklerinin ortadan kaldırılabileceği ya da azaltılabileceği savunulmaktadır.

Çocuklar dış dünya ile ilk ilişkilerine ailelerinin aracılığı ile başlamakta, kendilerini erkek ya da kız olarak adlandırmadan önce ailelerinden, çevrelerinden sözle ifade edilmeyen bazı işaretler almaktadır. Kadın ve erkeklerin giyim tarzları, saç biçimleri söz konusu işaretlerden bazılarıdır. Bununla birlikte cinsiyetçi kalıp yargıları özellikle çocuklar için oyun ve oyuncak seçimlerinde kendini göstermektedir (Giddens, 2008: 208-209). Kongar’a (2019) göre her insanı önce aile sonra toplum eğitmektedir. Bireye toplumsal değerleri ve kuralları aktaran bu sürece "toplumsallaştırma" adı verilmekte, her toplumsal yapı ve o toplumsal yapı ile etkileşim içinde olan her devlet kendine uygun, kendi ideolojisini taşıyan bireyler yetiştirmek istemektedir. Bu nedenle devlet en büyük ağırlığı eğitime yani aile içi eğitime ve okullara vermektedir. Okul, toplumsal cinsiyet rollerine ilişkin yargıları öğrencilere öğretirken onları geleneksel cinsiyet rollerine uygun davranmaya yönlendirmekte, toplumsal cinsiyet ayrımcılığını teşvik etmektedir.

Ataerkil ideolojinin yaygınlaşmasına neden olan toplumsal kurumlardan söz ederken Louis Althusser'e başvurabiliriz. Althusser (2000) tüm ideolojik yaklaşımları mevcut sistemin kendini tekrar üretmesi için destek yapılar olarak kabul etmektedir. İdeoloji, toplumsal bütünlüğü yeniden üreten, sistemin yeniden üretilmesi için siyasal ve ekonomik iktidarın kullandığı ikna sürecidir. Toplumsal formasyonu ekonomik, siyasi ve ideolojik düzeylere ayıran Althusser, bu yapı içinde bireylerin kendilerini önceden belirlenmiş ilişkiler içinde bulduklarını, bireylerin rolleri önceden belirlendiği için toplumu bireylerarası ilişkilere indirgemenin doğru olmayacağını belirtmektedir. 
İlişkilerin bütününü göremeyen bireyler kendilerini özneler olarak görmekte, ideoloji de toplumsal ilişkilerin taşıyıcısı konumundaki bireyleri söz konusu ilişkilerin öznesi haline getirmektedir. İdeolojinin bazı aygıtlar aracılığıyla gerçekleştiğini belirten Althusser, bu aygıtları "devletin baskı aygıtları" ve "devletin ideolojik aygıtları" olarak ikiye ayırmaktadır. Devletin baskı aygıtları, hükümet, ordu, polis gibi kurumlardan oluşurken, ideolojik aygıtlar arasında din, eğitim kurumları, aile, hukuk kurumları, siyasal partiler, sendikalar, kitle iletişim araçları yer almaktadır. Aralarındaki temel fark, baskı aygıtların baskı, ideolojik aygıtların ise ideoloji kullanmasıdır.

\section{Üniversite Öğrencilerinin Toplumsal Cinsiyet Eşitliği Tutumları}

Üniversite öğrencilerinin toplumsal cinsiyet eşitliğine yönelik tutumlarını tespit etmeyi amaçlayan bu çalışmada veri toplama aracı olarak "Toplumsal Cinsiyet Eşitliği Tutum Ölçeği” kullanılmıştır. Araştırma sonucunda elde edilen bulgular tablolar halinde düzenlenmiş ve açıklanmıştır. Araştırmaya 122 kadın, 155 erkek öğrenci katılmıştır. Kadın öğrencileri yaş ortalaması $X=20.39$, erkeklerin $X=21.16$ 'dır. Toplam ortalama ise 20.82'dir.

\begin{tabular}{|c|c|c|c|c|c|c|}
\hline Sinif & Kadı & & Erkek & & Toplan & \\
\hline & $f$ & yüzde & $\mathrm{F}$ & yüzde & $f$ & yüzde \\
\hline 1.SinIf & 56 & 20.2 & 49 & 17.7 & 105 & 37.9 \\
\hline 2.Sinıf & 32 & 11.6 & 49 & 17.7 & 81 & 29.2 \\
\hline 3.Sinıf & 28 & 10.1 & 41 & 14.8 & 69 & 24.9 \\
\hline 4.Sinıf & 6 & 2.2 & 16 & 5.8 & 22 & 7.9 \\
\hline Toplam & 122 & 44 & 155 & 56 & 277 & 100 \\
\hline
\end{tabular}

Tablo 3: Öğrencilerin cinsiyete ve bulundukları sınıfa göre dağııımı.

Tablo 3'de görüldüğü gibi cinsiyet ve sınıf düzeylerine göre dağılım incelendiğinde toplam 122 (yüzde 44) kadın öğrencinin 56'sı (yüzde 20.2) 1. sınıf, 32'si (yüzde 11. 6) 2.sınıf, 28'i (yüzde 10.1) 3. sınıf ve 6’sı (yüzde 2.2) 4. sınıfta eğitim almaktadır. Toplam 155 (yüzde 56) erkek öğrencinin, 49’u (yüzde 17.7) 1. sınıf, 49’u (yüzde 17. 7) 2. sınıf, 41'i (14. 8) 3. sınıf ve 16'sı (yüzde 5. 8) 4. sınıfta bulunmaktadır. Araştırmada cinsiyet değişkenine ilişkin verilerin analizinde kullanılacak istatistiki test tekniğine karar vermek için normal dağılım test edilmiştir. Bu doğrultuda bir dağılımın normal olup olmadığını belirlemek için kullanılabilecek testlerden birisi olan Shapiro-Wilk testi uygulanmıştır. 


\begin{tabular}{llcc}
\hline & & Shapiro-Wilk & \\
& & & \\
& İstatistik & Sd & $\mathrm{P}$ \\
TCE Ölçeği & 0.93 & 277 & 0.00 \\
\hline
\end{tabular}

Tablo 4: Öğrencilerin Toplumsal Cinsiyet Eşitliği Tutum Puanlarına Yönelik Normallik Testi

$P$ değerinin $a=0,05$ ’ten küçük çıkması dağılımın normal olmadığını göstermektedir. Normal dağılım çan eğrisi şeklinde ve dikey eksene göre simetrik bir dağılım göstermektedir. Normal dağılımda ortalama, mod ve medyan çakışıktır. Bu değerler birbirine yaklaştığı ölçüde dağılım, normal dağılıma yaklaşmakta, birbirinden uzaklaştığı ölçüde dağılım çarpıklaşmaktadır. Normal dağılımı test etmenin bir yolu basıklık ve çarpıklık katsayılarına bakmaktır. Çarpıklık katsayısı normal dağılımda 0 olarak kabul edilmektedir. Negatif çarpıklık katsayısı sağa çarpık dağılımı, pozitif çarpıklık katsayısı da sola çarpık dağılımı göstermektedir. Benzer şekilde basıklık katsayısı da normal dağılımda 0'dır. Pozitif basıklık katsayısı sivri dağılımı, negatif basıklık katsayısı ise basık bir dağılımı göstermektedir (Demir, 2017). Sağa çarpık dağılımda puanların önemli bir kısmı aritmetik ortalamanın altında kalmakta, dağılım düşük puanlarda sola doğru yığılma göstermektedir. Sola çarpık dağılımda ise puanların önemli bir kısmı aritmetik ortalamanın üzerinde kalmakta, dağılım yüksek puanlarda sağa doğru yığılmaktadır. Basıklık katsayısı da dağılımın aritmetik ortalamanın etrafında yığılması ya da aritmetik ortalamadan uzaklaşmasıdır. Basıklık katsayısı 0'dan büyük olduğunda dağılım sivri, 0'dan küçük olduğunda ise dağılım basık olmaktadır. Puanlar çok fazla çeşitlilik göstermiyorsa dağılım sivri olmakta, puanlar çeşitlendiğinde ise dağılım basık gerçekleşmektedir (Başol, 2013).

\section{TCE Ölçeği}

\begin{tabular}{lllcl}
\hline $\mathrm{x}$ & $\mathrm{me}$ & sd & Çarpıklık Katsayısı & Basıklık Katsayısı \\
36.57 & 35 & 7.76 & 1.162 & 2.70 \\
\hline
\end{tabular}

Tablo 5: Öğrencilerin Toplumsal Cinsiyet Eşitliği Tutum Puanlarının Ortalama, Medyan, Standart Sapma, Çarpıklık Katsayısı ve Basıklık Katsayısı 
Bu çalışmada çarpıklık katsayısına göre dağılım 0'dan büyük olması nedeniyle sağa çarpık, basıklık katsayısı ise dağılım 2'den büyük olduğu için sivridir. Bu nedenle öğrencilerin toplumsal cinsiyet eşitliğine yönelik tutumlarının cinsiyet değişkenine göre anlamlı bir farklılık gösterip göstermediğinin test edilmesi için parametrik olmayan test tekniklerinden Mann - Whitney U testi, üçlü ve daha çok gruplarda (1., 2., 3. ve 4.sınıf) Kruskall-Wallis-H testi kullanılmıştır.

\begin{tabular}{lccccc}
\hline Cinsiyet & N & Sıra Ortalaması & Sıra Toplamı & U & P \\
\hline Kadın & 122 & 162.89 & 25248.5 & 5751.5 & 0.00 \\
Erkek & 155 & 108.64 & 13254.5 & & \\
\hline
\end{tabular}

${ }^{* *} \mathrm{p}<0.05$

Tablo 6: Öğrencilerin Toplumsal Cinsiyet Eşitliği Tutum Puanlarının Cinsiyete Göre Mann-Whitney U Testi Sonuçları

Mann-Whitney $U$ testi sonucunda cinsiyete göre farklılık tespit edilmiştir $(U=5751.5 p$ <0.05). Kadın öğrencilerin ölçekten almış oldukları puan ortalaması, erkek öğrencilerin puan ortalamasından daha yüksektir. Dolayısıyla bu bulgular kadın öğrencilerin erkek öğrencilere göre daha eşitlikçi toplumsal cinsiyet rol tutumuna sahip olduğunu göstermektedir.

\begin{tabular}{llcll}
\hline Sinıf & $N$ & Sira Ortalaması & $X^{2}$ & $P$ \\
\hline 1 & 105 & 139.2 & 0.342 & 0.95 \\
2 & 81 & 140.2 & & \\
3 & 69 & 135.1 & & \\
4 & 22 & 145.8 & & \\
\hline
\end{tabular}

${ }^{\star *} \mathrm{p}>0.05$

Tablo 7: Sınıf Değişkenine Göre Kruskal Wallis-H Sonuçları 
Tablo 7'de görüldüğü gibi araştırmaya katılan öğrencilerin "Cinsiyet Eşitliği Tutum" puanlarının bulundukları sınıflara göre farklılık oluşturup oluşturmadığını tespit için uygulanan Kruskal Wallis-H testi sonucunda sınıf değişkenine göre anlamlı farklılık tespit edilmemiştir ( $p>0.05$ ). Örneğin 1. Sınıf öğrencileri ile 4.sınıf öğrencileri arasında dikkate değer bir fark söz konusu değildir. Bu durum üniversite eğitiminin toplumsal cinsiyet eşitliği konusunda öğrencilere katkı sağlamadığı şeklinde değerlendirilebilir.

\begin{tabular}{cccccc}
\hline & Kişi Sayısı & $\begin{array}{c}\text { En Düşük } \\
\text { Puan }\end{array}$ & $\begin{array}{c}\text { En Yüksek } \\
\text { Puan }\end{array}$ & $\mathrm{X}$ & $\begin{array}{c}\text { Standart } \\
\text { Sapma }\end{array}$ \\
\hline Puan Değeri & 277 & 15 & 75 & 36.57 & 7.76 \\
\hline
\end{tabular}

Tablo 8: Öğrencilerin Ölçekten Elde Ettiği En Az ve En Yüksek Puan

En yüksek puan 75 en az puan 15'dir. Uygulanan ölçeğin puan ortalaması $x=36.57$, ss=7.76'dır. Elde edilen puandan hareketle, öğrencilerin orta düzeyde toplumsal cinsiyet eşitliğine yönelik algıya sahip oldukları söylenebilir.

\section{Öğrencilerin Ölçekte Yer Alan İfadelere İlişkin Görüşleri}

Ölçekte yer alan birinci önerme erkeklerin statüsü yüksek mesleklerde çalışmasına ilişkindir. Çalışmaya katılanlardan bir kadın ve iki erkek öğrenci önermeyi boş bırakmıştır. Önermeye kadın öğrencilerin yüzde 8.8’i kesinlikle katıldığını, yüzde 8.8’i de katıldığını belirtmiştir (toplam katılan yüzde 17.6). Erkek öğrencilerin yüzde 13.1'i kesinlikle katıldığını belirtirken yüzde 19.6'sı katıldığını belirtmiştir (toplam katılan yüzde 32.7). Bu sonuç, ataerkil ideolojiyi benimseyen erkek öğrencilerin oranının kadın öğrencilere göre daha yüksek olduğunu göstermesi açısından önemlidir.

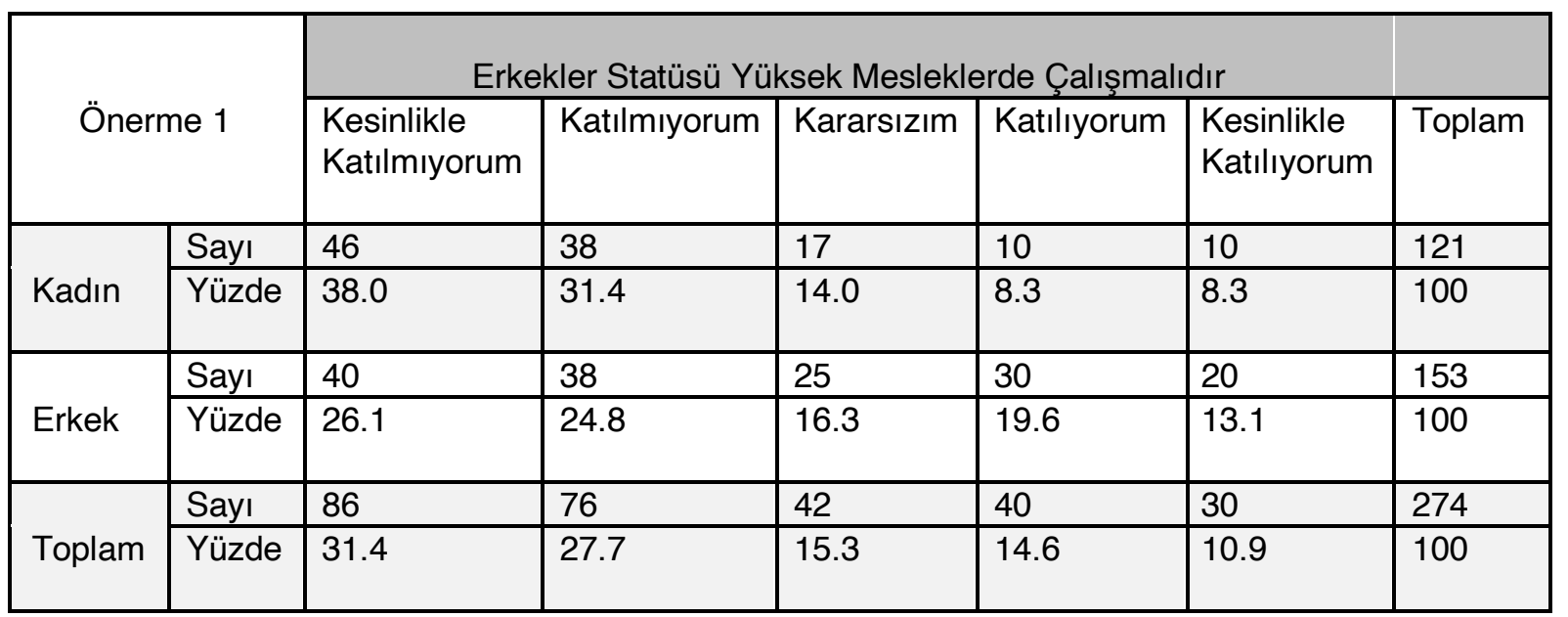

Tablo 9: Erkekler Statüsü Yüksek Mesleklerde Çalışmalıdır 
TÜIK (2018) verilerine göre şirketlerde üst düzey ve orta kademe yönetici konumundaki kadın oranı 2012 yılında yüzde 14.4 iken, 2017 yılında yüzde 17.3 olarak tespit edilmiştir. Yılmaz ve arkadaşlarının (2009) yaptığı çalışmada ise "Çalışma yaşamında aynı statüde çalışan kadın ve erkekler arasında terfilerde erkeğe öncelik verilmesi normaldir” önermesine kadın öğrencilerin yüzde 99.2'si erkek öğrencilerin ise yüzde 79'u katılmadığını belirtmiştir. Karasu ve arkadaşlarının (2017) yaptığı çalışmada ise bu önermeye kadın öğrencilerin yüzde 24.8'i kararsız olduklarını belirtirken, erkeklerin yüzde 25.8'i tamamen katıldıklarını belirtmiştir. Kahraman ve arkadaşlarının (2015) çalışmasında ise önermeye katılanların oranı yüzde 36.4, katılmayanların oranı yüzde 61.8'dir.

\begin{tabular}{|c|c|c|c|c|c|c|c|}
\hline \multirow{2}{*}{\multicolumn{2}{|c|}{ Önerme 2}} & \multicolumn{6}{|c|}{ Erkekler Kadınlara Göre Daha Mantıklıdır } \\
\hline & & Kesinlikle & Katılmıyorum & Kararsızım & Katılıyorum & Kesinlikle & Toplam \\
\hline \multirow[b]{2}{*}{ Kadın } & Sayı & 75 & 33 & 5 & 5 & 4 & 122 \\
\hline & Yüzde & 61.5 & 27.0 & 4.1 & 4.1 & 3.3 & 100 \\
\hline \multirow[b]{2}{*}{ Erkek } & Sayı & 47 & 56 & 28 & 11 & 13 & 155 \\
\hline & Yüzde & 30.3 & 36.1 & 18.1 & 7.1 & 8.4 & 100 \\
\hline \multirow[b]{2}{*}{ Toplam } & Sayı & 122 & 89 & 33 & 16 & 17 & 277 \\
\hline & Yüzde & 44.0 & 32.1 & 11.9 & 5.8 & 6.1 & 100 \\
\hline
\end{tabular}

Tablo 10: Erkekler Kadınlara Göre Daha Mantıkıdır

Tablo 10'da görülen erkeklerin kadınlara göre daha mantıklı olduğuna iliş̧kin önermeye kadın öğrencilerin yüzde 61.5’i kesinlikle katılmadığını, yüzde 27.0’ katılmadığını belirtmiştir (toplam katılmayan yüzde 88.5). Erkek öğrencilerin ise yüzde 30.3'ü kesinlikle katılmadığını belirtirken yüzde 36.1'i katılmadığını belirtmiştir (toplam katılmayan yüzde 66.4). Önermeye kadın öğrencilerin yüksek oranda katılmadığı gözlenirken erkek öğrencilerin daha az oranda katılmadığı gözlenmiştir. Bununla birlikte erkek öğrencilerin kararsız olma oranı kadın öğrencilere göre oldukça yüksektir. 


\begin{tabular}{|l|l|l|l|l|l|l|l|}
\hline \multirow{2}{*}{ Önerme 3 } & \multicolumn{6}{|c|}{ Çocuk Sahibi OIma Kararııı Eşler Birlikte Vermelidir } \\
\cline { 2 - 8 } & $\begin{array}{l}\text { Kesinlikle } \\
\text { Katılmıyorum }\end{array}$ & Katılııırum & Kararsızım & Katılıyorum & $\begin{array}{l}\text { Kesinlikle } \\
\text { Katılıyorum }\end{array}$ & Toplam \\
\hline \multirow{3}{*}{ Kadın } & Sayı & 1 & 1 & 2 & 18 & 100 & 122 \\
\cline { 2 - 8 } & Yüzde & 0.8 & 0.8 & 1.6 & 14.8 & 82.0 & 100 \\
\hline \multirow{3}{*}{ Erkek } & Sayı & 0 & 2 & 5 & 32 & 115 & 154 \\
\cline { 2 - 8 } & Yüzde & 0.0 & 1.3 & 3.2 & 20.8 & 74.7 & 100 \\
\hline \multirow{3}{*}{ Toplam } & Sayı & 1 & 3 & 7 & 50 & 215 & 276 \\
\cline { 2 - 8 } & Yüzde & 0.4 & 1.1 & 2.5 & 18.1 & 77.9 & 100 \\
\hline
\end{tabular}

Tablo 11: Çocuk Sahibi Olma Kararını Eşler Birlikte Vermelidir

Çocuk sahibi olma kararına eşlerin birlikte karar vermesine ilişkin önermeye bir erkek öğrenci yanıt vermemiştir. Önermeye kadın öğrencilerin toplamda yüzde 96.8'i katıldığını, erkek öğrencilerin ise toplamda yüzde 95.5’i katıldığını ifade etmiştir. Dolayısıyla öğrenciler bu önermeye büyük oranda katılarak eşitlikçi bir bakış açısı sergilemişlerdir. Seven'in (2019) çalışmasında ise aynı önermeye kadınların yüzde 76.5’i tamamen katıldığını belirtirken erkeklerin yüzde 46. 2'si tamamen katıldığını belirtmiştir.

\begin{tabular}{|l|l|l|l|l|l|l|l|}
\hline \multirow{2}{*}{ Önerme 4} & \multicolumn{6}{|c|}{ Yuvayı Dişi Kuş Yapar } \\
\cline { 3 - 8 } & $\begin{array}{l}\text { Kesinlikle } \\
\text { Katımıyorum }\end{array}$ & Katımıyorum & Kararsızım & Katılıyorum & $\begin{array}{l}\text { Kesinlikle } \\
\text { Katılıyorum }\end{array}$ & Toplam \\
\hline \multirow{3}{*}{ Kadın } & Sayı & 28 & 30 & 32 & 17 & 15 & 122 \\
\cline { 2 - 8 } & Yüzde & 23.0 & 24.6 & 26.2 & 13.9 & 12.3 & 100 \\
\hline \multirow{3}{*}{ Erkek } & Sayı & 27 & 17 & 59 & 31 & 19 & 153 \\
\cline { 2 - 8 } & Yüzde & 17.6 & 11.1 & 38.6 & 20.3 & 12.4 & 100 \\
\hline \multirow{3}{*}{ Toplam } & Sayı & 55 & 47 & 91 & 48 & 34 & 275 \\
\cline { 2 - 8 } & Yüzde & 20.0 & 17.1 & 33.1 & 17.5 & 12.4 & 100 \\
\hline
\end{tabular}

Tablo12: Yuvayı Dişi Kuş Yapar

"Yuvayı dişi kuş yapar" önermesine iki erkek öğrenci yanıt vermemiş, kadın öğrencilerin yüzde 12.3'ü kesinlikle katıldığını, yüzde 13.9'u katıldığını belirtmiştir (toplam katılan yüzde 26.2). Erkek öğrencilerin ise yüzde 12.4'ı kesinlikle katıldığını 
belirtirken yüzde 20.3’i katıldığını belirtmiştir (toplam katılan yüzde 32.7). Dolayısıyla bu önermede kadın ve erkek öğrencilerin geleneksel yaklaşımın etkisi altında kaldıkları gözlenmektedir.

Ataerkil yapı içinde kadının yerinin evi olduğu görüşü hakimdir. Herhangi bir zorunluluk olmadıkça kadının dışarıda çalışması uygun bulunmamaktadır. Ev işleri ve çocukların bakımı ise kadının sorumluluğundadır. Üniversite öğrencilerinin toplumsal cinsiyet eşitliği konusundaki tutumlarının saptanması amacıyla gerçekleştirilen çeşitli araştırmalarda genellikle kadın öğrencilerin eşitlikçi tutumları daha üst seviyelerde saptanmıştır. Bununla birlikte cinsiyetçi rol kalıpları hakkında halen geleneksel bakış açısının etkisinde kaldıkları da elde edilen bulgular arasında yer almaktadır (Baykal,1991; Elgün ve Alemdar, 2017; Öngen ve Aytaç, 2013; Pınar vd., 2008).

\begin{tabular}{|c|c|c|c|c|c|c|c|}
\hline \multicolumn{2}{|c|}{ Önerme 5} & \multicolumn{6}{|c|}{$\begin{array}{l}\text { Kadının En Önemli Rolü Evine Özen Göstermek ve Ailesi İçin Yemek } \\
\text { Yapmaktır }\end{array}$} \\
\hline & & $\begin{array}{l}\text { Kesinlikle } \\
\text { Katılmıyorum }\end{array}$ & Katılmıyorum & Kararsızım & Katılıyorum & $\begin{array}{l}\text { Kesinlikle } \\
\text { Katılıyorum }\end{array}$ & Toplam \\
\hline \multirow[b]{2}{*}{ Kadın } & Sayı & 72 & 30 & 9 & 0 & 9 & 120 \\
\hline & Yüzde & 60.0 & 25.0 & 7.5 & 0.0 & 7.5 & 100 \\
\hline \multirow[b]{2}{*}{ Erkek } & Sayı & 46 & 54 & 38 & 7 & 9 & 154 \\
\hline & Yüzde & 29.9 & 35.1 & 24.7 & 4.5 & 5.8 & 100 \\
\hline \multirow[b]{2}{*}{ Toplam } & Sayı & 118 & 84 & 47 & 7 & 18 & 274 \\
\hline & Yüzde & 43.1 & 30.7 & 17.2 & 2.6 & 6.6 & 100 \\
\hline
\end{tabular}

Tablo 13: Kadının En Önemli Rolü Evine Özen Göstermek ve Ailesi İçin Yemek Yapmaktır

Tablo 13'deki beşinci önermeyi iki kadın, bir erkek öğrenci boş bırakmıştır. Önermeye kadın öğrencilerin yüzde 60’ kesinlikle katılmadığını, yüzde 25’i de katılmadığını belirtmiştir (toplam katılmayan yüzde 85). Erkek Öğrencilerin ise yüzde 29.9'u kesinlikle katılmadığını belirtirken yüzde 35.1'i katılmadığını belirtmiştir (toplam katılmayan yüzde 65). Bu önermede kadın öğrencilerin daha eşitlikçi bir tutum sergiledikleri gözlenmektedir. Erkek öğrencilerin önemli bir oranı da (yüzde 24.7) kararsız olduğunu belirtmiştir. 
Önermeye katılmayan kadın öğrencilerin yüzdesi yüksek olmakla birlikte günlük yaşamda ev işlerinin önemli bir bölümünü kadınlar yapmaktadır. Ayrıca kitle iletişim araçlarında kadınlar genellikle yemek yaparken, çamaşır-bulaşık yıkarken, çocuklarıyla ilgilenirken ya da temizlik yaparken temsil edilmektedir. Bu durum devletin ideolojik aygıtları içinde yer alan kitle iletişim araçlarının geleneksel yapının devam ettirilmesi yönünde hareket ettiğini göstermesi açısından önemlidir. Bununla birlikte çalışma istatistiklerinde kadınların iş gücüne katılma oranları erkeklerin oldukça gerisinde kalmaktadır. Yılmaz ve arkadaşlarının (2009) çalışmasında da "Ailede ev işlerinin sorumluluğu kadına ait olmalıdır” önermesini erkek öğrenciler yüzde 40.1 oranında onaylarken, Esen ve arkadaşlarının 2017 yılında yaptıkları araştırmada "Kadınların birinci görevi ev işlerini üstlenmektedir" önermesine kadınların yüzde 57.4'ü, erkeklerin yüzde 27.4'ü katılmadıklarını ifade etmişlerdir. Türkiye Nüfus ve Sağlık Araştırması 2013 yılı sonuçlarına göre de kadınların yüzde 75.2 oranında 'Yemek, bulaşık çamaşır, ütü ve temizlik gibi ev işlerini erkekler de yapmalıdır" ifadesine katıldıkları tespit edilmiştir (Türkiye İstatistik Kurumu, 2015).

\begin{tabular}{|c|c|c|c|c|c|c|c|}
\hline & \multicolumn{5}{|c|}{ Kız ve Erkek Çocukların Eğitim Hakkı Eşit Olmalıdır } & \multirow[b]{2}{*}{ Toplam } \\
\hline & & $\begin{array}{l}\text { Kesinlikle } \\
\text { Katılmıyorum }\end{array}$ & Katılmıyorum & Kararsızı & Katılıyorum & $\begin{array}{l}\text { Kesinlikle } \\
\text { Katılıyorum }\end{array}$ & \\
\hline \multirow[b]{2}{*}{ Kadın } & Sayı & 3 & 2 & 3 & 6 & 107 & 121 \\
\hline & Yüzde & 2.5 & 1.7 & 2.5 & 5.0 & 88.4 & 100 \\
\hline \multirow[b]{2}{*}{ Erkek } & Sayı & 1 & 3 & 5 & 13 & 131 & 153 \\
\hline & Yüzde & 0.7 & 2.0 & 3.3 & 8.5 & 85.6 & 100 \\
\hline \multirow[b]{2}{*}{ Toplam } & Sayı & 4 & 5 & 8 & 19 & 238 & 274 \\
\hline & Yüzde & 1.5 & 1.8 & 2.9 & 6.9 & 86.9 & 100 \\
\hline
\end{tabular}

Tablo 14: Kız ve Erkek Çocukların Eğitim Hakkı Eşit Olmalıdır

“Kız ve erkek çocukların eğitim hakkının eşit olmalıdır” önermesini bir kadın ve iki erkek öğrenci boş bırakmış, kadın öğrenciler toplamda yüzde 93.4, erkek öğrenciler ise toplamda yüzde 94.1 oranında katıldıklarını ifade etmişlerdir. Bu önermede öğrencilerin büyük ölçüde eşitlikçi yaklaşımı benimsedikleri saptanmıştır. Bununla birlikte KONDA tarafından 2018 yılında Türkiye genelinde 5793 kişiyle yüz yüze 
görüşülerek gerçekleştirilen “Hayat Tarzları” araştırması kadınların yüzde 10'nun okuryazar olmadığını göstermektedir. Ayrıca kadınların yüzde 51'i ortaokul, yüzde 25’i lise düzeyinde, erkeklerin ise yüzde 45'i ortaokul, yüzde 33'ü ise lise düzeyinde eğitim almıştır (KONDA, 2019). Türkiye Nüfus ve Sağlık Araştırmaları (TNSA) 2018'e göre ülkemizde genç yaştaki kadınlar, kendilerinden daha büyük yaşlardaki kadınlara göre daha fazla eğitim almaktadır. 15- 19 yaş aralığında okur yazarlık oranı yüzde 99, 4549 yaş aralığında ise yüzde 89'dur. (Hacettepe Üniversitesi Nüfus Etütleri Enstitüsü, 2019).

\begin{tabular}{|l|l|l|l|l|l|l|l|}
\hline \multicolumn{2}{|c|}{} & \multicolumn{6}{|c|}{ Bir Genç Kız Evlenene Kadar Babasının Sözünü Dinlemelidir } \\
\cline { 2 - 8 } & $\begin{array}{l}\text { Kesinlikle } \\
\text { Katılmıyorum }\end{array}$ & Katılmıyorum & Kararsızım & Katılıyorum & $\begin{array}{l}\text { Kesinlikle } \\
\text { Katılıyorum }\end{array}$ & Toplam \\
\hline \multirow{3}{*}{ Kadın } & Sayı & 40 & & & & \\
\cline { 2 - 8 } & Yüzde & 33.6 & 26.1 & 31.1 & 6.7 & 2.5 & 100 \\
\hline \multirow{3}{*}{ Erkek } & Sayı & 20 & 23 & 79 & 21 & 12 & 155 \\
\cline { 2 - 8 } & Yüzde & 12.9 & 14.8 & 51.0 & 13.5 & 7.7 & 100 \\
\hline \multirow{3}{*}{ Toplam } & Sayı & 60 & 54 & 116 & 29 & 15 & 274 \\
\cline { 2 - 8 } & Yüzde & 21.9 & 19.7 & 42.3 & 10.6 & 5.5 & 100 \\
\hline
\end{tabular}

Tablo 15: Bir Genç Kız Evlenene Kadar Babasının Sözünü Dinlemelidir

Tablo 15'deki yedinci önermeyi üç kadın öğrenci boş bırakmıştır. Kadın öğrencilerin yüzde 2.5’i bu önermeye kesinlikle katıldığını, yüzde 6.7’i de katıldığını belirtmiştir (toplam katılan yüzde 9.2). Erkek Öğrencilerin ise yüzde 7.7'si kesinlikle katıldığını belirtirken yüzde 13.5’i katıldığını belirtmiştir (toplam katılan yüzde 21.2). Hem kadın hem erkek öğrenciler arasında kararsızların oranı ise oldukça yüksektir (yüzde 42.3). Kahraman ve arkadaşlarının (2015) çalışmasında ise "Bir kadın evlenene kadar babasını sözünü dinlemelidir” önermesine katılımcıların yüzde 69.1 katılıyorum yanıtını vermiştir. Kahraman ve arkadaşlarının da belirttiği gibi bu önermede kadınların kendi başlarına karar vermeleri konusunda ataerkil düşünce yapısının etkisi gözlenmektedir. Ataerkil yapı içinde baba, ailenin karar verici ve tek yetkili kişisi olarak eşi ve çocukları üzerinde söz söyleme hakkı olan otoritedir. Seven'in (2019) çalışmasında ise bu önermeye kadınların yüzde 6.5 ', erkeklerin ise yüzde 13.5 'i tamamen katıldığını 
belirtmiştir. Kadınların yüzde 18.5'i, erkeklerin yüzde 9.6’sı ise kesinlikle katılmadığını belirtmiştir.

\begin{tabular}{|c|c|c|c|c|c|c|c|}
\hline \multirow{2}{*}{\multicolumn{2}{|c|}{ Önerme 8}} & \multicolumn{4}{|c|}{ Erkeklerin Ev İşleri Yapmasını Önemserim } & \multirow{2}{*}{$\begin{array}{l}\text { Kesinlikle } \\
\text { Katılıyorum }\end{array}$} & \multirow[b]{2}{*}{ Toplam } \\
\hline & & Kesinlikle & Katılmıyorum & Kararsızım & Katılıyorum & & \\
\hline \multirow[b]{2}{*}{ Kadın } & Sayı & 3 & 2 & 11 & 48 & 58 & 122 \\
\hline & Yüzde & 2.5 & 1.6 & 9.0 & 39.3 & 47.5 & 100 \\
\hline \multirow[b]{2}{*}{ Erkek } & Sayı & 9 & 8 & 46 & 51 & 40 & 154 \\
\hline & Yüzde & 5.8 & 5.2 & 29.9 & 33.1 & 26.0 & 100 \\
\hline \multirow[b]{2}{*}{ Toplam } & Sayı & 12 & 10 & 57 & 99 & 98 & 276 \\
\hline & Yüzde & 4.3 & 3.6 & 20.7 & 35.9 & 35.5 & 100 \\
\hline
\end{tabular}

Tablo 16: Erkeklerin Ev İşlerini Yapmasını Önemserim

"Erkeklerin ev işleri yapmasını önemserim" önermesini bir erkek öğrenci boş bırakmıştır. Önermeye kadın öğrencilerin toplamda katılım oranı yüzde 86.8, erkek öğrencilerin ise toplam katılım oranı yüzde 59.1'dir. Bu önermede erkek öğrenciler arasında kararsızların oranı yüzde 29.9'dur. Önermede kadın öğrencilerin erkeklere göre daha eşitlikçi tutum sergiledikleri görülmekte, erkek öğrenciler ise eşitlikçi role mesafeli yaklaşmaktadır. Kandiyoti'nin (1997) de belirttiği gibi ev dışında çalışan kadınların hem iş hem de ev sorumluluklarını birlikte yürütmeleri sonucunda yaşadıkları sorunlar yeni rol taleplerinden uzak kalmak isteyen erkeklere az oranda yansıtılmakta, erkeğe ait rol değişimden sınırlı oranda etkilenmektedir. Ayrıca 2016 TÜİK verileri, evin badana ve boyası, küçük onarım ve tamirler ile faturaların ödenmesi dışında ev işlerini çoğunlukla kadınların yaptığını göstermektedir. Ayrıca devletin ideolojik aygıtları içinde yer alan aile, eğitim kurumları ve kitle iletişim araçları ev işlerini kadının görevi olarak yansıtmaktadır. Okul kitaplarında yer verilen yazılı ve görsel bilgiler, iletişim araçlarının ilettiği mesajlar ataerkil yapının yeniden üretimine katkı sağlamaktadır. Çalışma yaşamına katılmış olsa bile ev içinde kadının üstlenmek durumunda kaldığı rollerde değişiklik olmamakta, aksine iş yükü daha da artmaktadır. Erkek öğrencilerin eşitlikçi tutumda olmaması, ataerkil yapının özellikle ev içi rollerde erkekler tarafından desteklendiğini göstermektedir. Bir çalışmada (Birleşik Metal-İş 
Sendikası Araştırma Merkezi, 2020) kadınların yarısından fazlasının ev işlerini kendilerinin yaptığı tespit edilmiştir. Ev dışında çalışıyor olmasına rağmen evli kadınların yalnızca yüzde 13'ü ev işlerini eşleri ile paylaştığını belirtmiştir. Ayrıca kadın katılımcıların tamamı iş günlerinde de olsa evde yemek, temizlik, çocuk bakımı, ev toplama, bulaşık, çamaşır ve ütü gibi ev işlerinden en az birini yaptıklarını söylemişlerdir. Esen ve arkadaşlarının (2017) çalışmasında ise "Erkekler de çamaşır, bulaşık gibi ev işlerini yapmalıdır” önermesine kadınlar yüzde 66.6 oranında, erkekler yüzde 27.4 oranında kesinlikle katıldığını ifade etmiştir. Araştırma bulguları, ev dışında çalışsalar bile kadınların erkeklerden daha fazla ev işi yaptığını, erkeklerin çalışmasalar da ev işleri yapmadıklarını göstermektedir. Çalışan kadınlar ortalama 1.5 saat, çalışan erkekler 10 dakika ev işi yapmaktadır (KONDA, 2019).

\begin{tabular}{|l|l|l|l|l|l|l|l|}
\hline \multirow{2}{*}{ Önerme 9 } & \multicolumn{6}{|c|}{ Erkekler Ağlamaz } \\
\cline { 3 - 8 } & $\begin{array}{l}\text { Kesinlikle } \\
\text { Katılmıyorum }\end{array}$ & Katılmıyorum & Kararsızım & Katılıyorum & $\begin{array}{l}\text { Kesinlikle } \\
\text { Katılıyorum }\end{array}$ & Toplam \\
\hline \multirow{3}{*}{ Kadın } & Sayı & 88 & 26 & 3 & 3 & 1 & 121 \\
\cline { 2 - 8 } & Yüzde & 72.7 & 21.5 & 2.5 & 2.5 & 0.8 & 100 \\
\hline \multirow{3}{*}{ Erkek } & Sayı & 87 & 37 & 15 & 5 & 9 & 153 \\
\cline { 2 - 8 } & Yüzde & 56.9 & 24.2 & 9.8 & 3.3 & 5.9 & 100 \\
\hline \multirow{3}{*}{ Toplam } & Sayı & 175 & 63 & 18 & 8 & 10 & 274 \\
\cline { 2 - 8 } & Yüzde & 63.9 & 23.0 & 6.6 & 2.9 & 3.6 & 100 \\
\hline
\end{tabular}

Tablo 17: Erkekler Ağlamaz

Bir kadın ve iki erkek öğrenci "erkekler ağlamaz" önermesini boş bırakmıştır. Önermeye kadın öğrencilerin yüzde 72.7’i kesinlikle katılmadığını, yüzde 21.5’i katılmadığını belirtmiştir (toplam katılmayan yüzde 94.2). Erkek öğrencilerin ise yüzde 56.9'u kesinlikle katılmadığını belirtirken yüzde 24.2'i katılmadığını belirtmiştir (toplam katılmayan yüzde 81.1). Önermeye kadın ve erkek öğrencilerin yüksek oranda katılmadığı dolayısıyla eşitlikçi yaklaşıma yakın oldukları saptanmıştır. Kahraman ve arkadaşlarının (2015) çalışmasında "Erkekler toplum içinde ağlamamalıdır" önermesine katılanların oranı yüzde 48, katılmayanların oranı yüzde 51.5 'dir. KONDA'nın (2019) çalışmasında ise toplumumuzda erkeklere yakıştırılan ve duyguları belli etmemeyi simgeleyen "Erkek adam ağlamaz" anlayışının genel olarak 
onaylanmadığı saptanmıştır. Toplumsal cinsiyet rolleri çerçevesinde erkeğe yakıştırılan ve doğdukları günden itibaren erkeklere dayatılan bu anlayışın tahmin edilenin tersine yaygın kabul görmemesi geleneksel erkeklik rollerine ilişkin bir tanımın kabul edilmemesi açısından önemli bir tespittir.

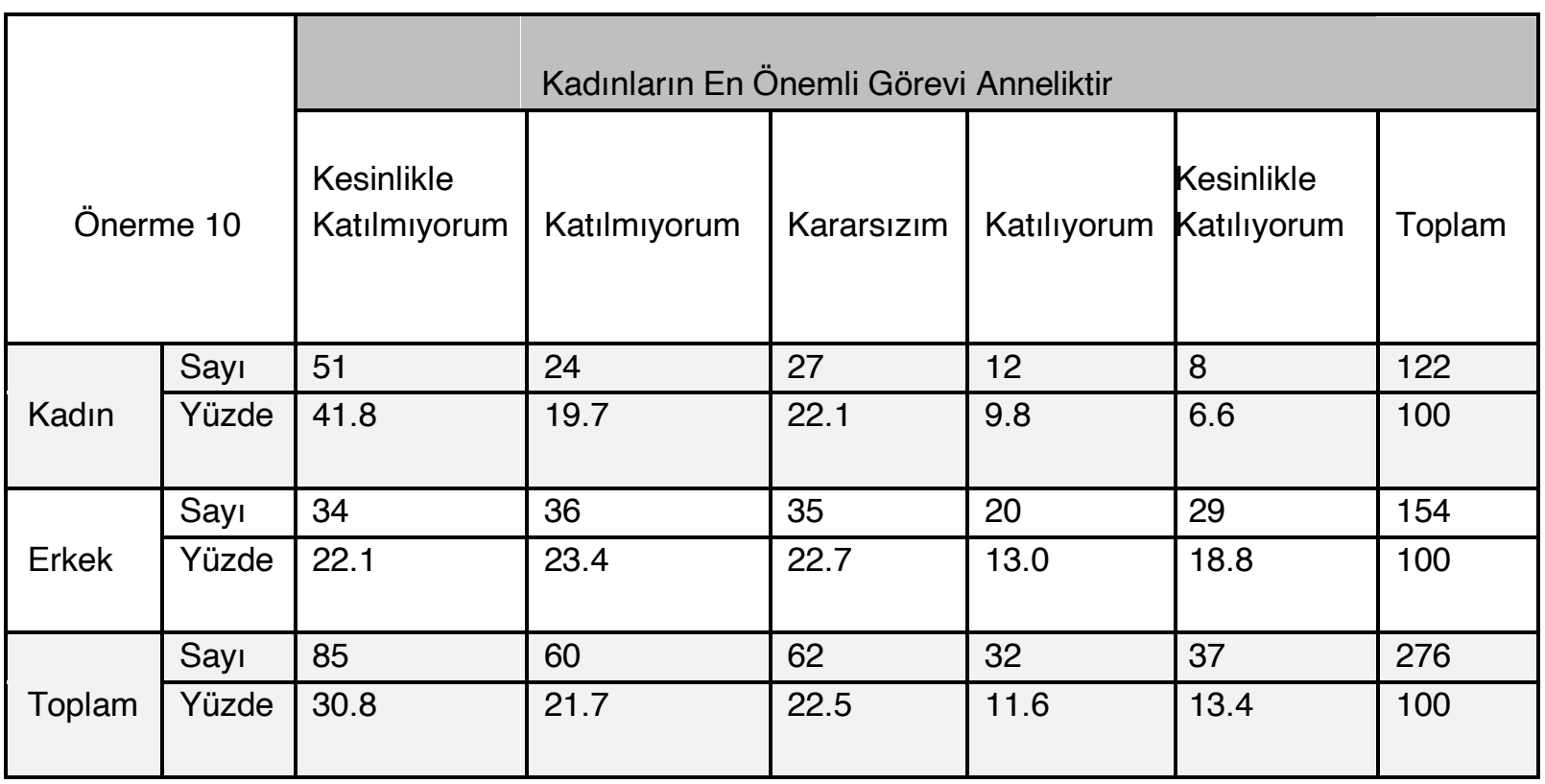

Tablo 18: Kadınların En Önemli Görevi Anneliktir

Kadınların en önemli görevinin annelik olduğu önermesini bir erkek öğrenci boş bırakmıştır. Önermeye katılmadığını ya da kesinlikle katılmadığını belirten kadın öğrencilerin oranı yüzde 61.5 , erkek öğrencilerin oranı ise yüzde 45.5 'tir. Bununla birlikte kadın ve erkek öğrencilerin yüzde 22.5’i kararsız olduklarını ifade etmişlerdir. Bu sonuç geleneksel toplumsal cinsiyet rolleri çerçevesinde düşünen öğrenci oranının yüksek olduğunu göstermesi açısından önemlidir. Geleneksel yaklaşım içinde annelik en önemli görevler arasında sayılmaktadır. Minibaş'ın (1998) belirttiği gibi kadının kendisine uygun bulduğu öncelikli rol "eş annelik" ve devamında ev kadınlığıdır. Karasu ve arkadaşlarının (2017) çalışmasında bu önermeye kadınların yüzde 25’i, erkeklerin yüzde 30.8'i katılmadıklarını, Seven'in (2019) çalışmasında ise kızların yüzde 39.8'i, erkeklerin yüzde 17.3'ü kesinlikle katılmadıklarını belirtmiştir. 


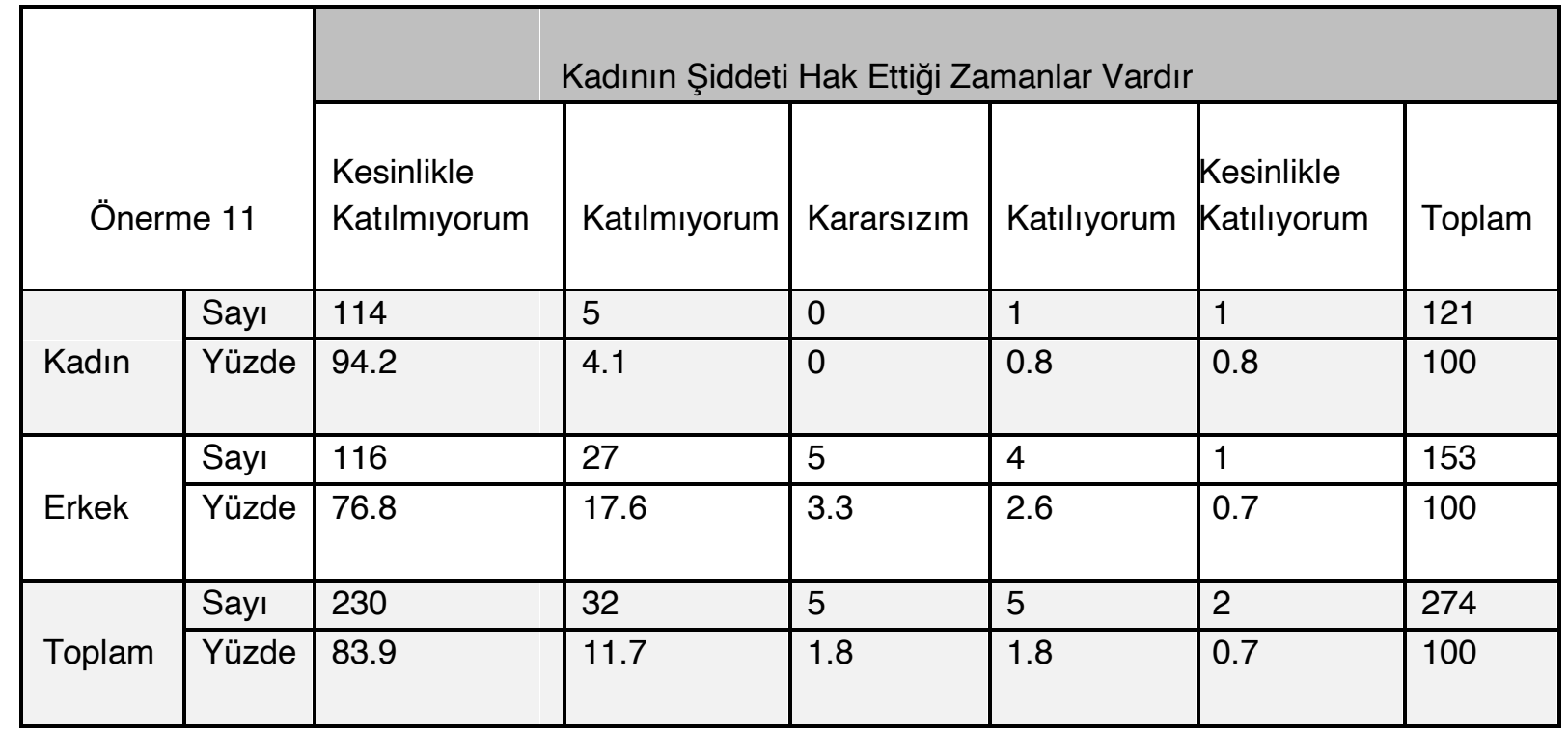

Tablo 19: Kadının Şiddeti Hak Ettiği Zamanlar Vardır

"Kadınların şiddeti hak ettiği zamanlar vardır” önermesini bir kadın ve iki erkek öğrenci boş bırakmıştır. Önermeye kadın öğrencilerin yüzde 94.2'i kesinlikle katılmadığını, yüzde 4.1'i katılmadığını belirtmiştir (toplam katılmayan yüzde 98.3). Erkek öğrencilerin yüzde 76.8'i kesinlikle katılmadığını belirtirken yüzde 17.6'ı katılmadığını belirtmiştir (toplam katılmayan yüzde 94.4). Dolayısıyla kadın ve erkek öğrencilerin kadına yönelik şiddet söz konusu olduğunda eşitlikçi yaklaşımı benimsedikleri gözlenmiştir. Vefikuluçay ve arkadaşlarının (2007) çalışmasında, kocası tarafından kadına hak ettiği durumlarda şiddet uygulanabileceği yönündeki önermeye kadın öğrenciler yüzde 10.6 oranında onay verirken, Altıparmak'ın (2018) çalışmasında öğrencilerin yüzde 91.8'i önermeye katılmamış, yüzde 8.2'si katılmıştır. Türkiye Nüfus ve Sağlık Araştırması 2003 sonuçlarına göre ise "Kadın hak ediyorsa kocasından dayak yiyebilir" görüşüne kadınların yüzde 39'u destek vermiştir (Hacettepe Üniversitesi Nüfus Etütleri Enstitüsü, 2004: 40).

WEF'in 2018 raporuna göre ise Türkiye'de kadınların yaşamları boyunca toplumsal cinsiyete dayalı şiddete maruz kalma oranı yüzde 42'dir. Bu oran ile Türkiye, OECD ülkeleri arasında en kötü durumdaki ülke konumundadır. Başka bir deyişle Türkiye'de her 10 kadından 4'ü yaşamları boyunca cinsiyete dayalı şiddet görmektedir. Söz konusu şiddet genellikle kadınların yakın çevresinde bulunan erkekler tarafından 
gerçekleştirilmektedir. Bununla birlikte 2014 yılında ikincisi gerçekleştirilen “Türkiye'de Kadına Yönelik Aile İçi Şiddet Araştırması"nın bulguları arasında duygusal şiddetle karşılaşan kadınların oranı yüzde 44 olarak tespit edilmiştir. Cinsel şiddete maruz kalan kadınların fiziksel şiddetle karşılaşma oranı ise yüzde 35’tir. Aydın Adnan Menderes Üniversitesi, İletişim Fakültesi öğrencilerinin kadına yönelik şiddetle ilgili tutumları daha önce aynı konuda yapılan çalışmalarda elde edilen sonuçlarla ve Türkiye'de kadına yönelik şiddetin boyutlarıyla karşılaştıııldığında umut vericidir.

\begin{tabular}{|c|c|c|c|c|c|c|c|}
\hline \multirow{2}{*}{\multicolumn{2}{|c|}{ Önerme 12}} & \multicolumn{6}{|c|}{$\begin{array}{l}\text { Ailenin Geçimini Sağlayan Erkek Olduğu İçin Kadının Çalışmasına Gerek } \\
\text { Yoktur }\end{array}$} \\
\hline & & $\begin{array}{l}\text { Kesinlikle } \\
\text { Katılmıyorum }\end{array}$ & Katılmıyorum & Kararsızım & Katılıyorum & $\begin{array}{l}\text { Kesinlikle } \\
\text { Katılıyorum }\end{array}$ & Toplam \\
\hline \multirow[b]{2}{*}{ Kadın } & Sayı & 105 & 15 & 0 & 1 & 1 & 122 \\
\hline & Yüzde & 86.1 & 12.3 & 0.0 & 0.8 & 0.8 & 100 \\
\hline \multirow[b]{2}{*}{ Erkek } & Sayı & 93 & 39 & 15 & 5 & 3 & 155 \\
\hline & Yüzde & 60.0 & 25.2 & 9.7 & 3.2 & 1.9 & 100 \\
\hline \multirow[b]{2}{*}{ Toplam } & Sayı & 198 & 54 & 15 & 6 & 4 & 277 \\
\hline & Yüzde & 71.5 & 19.5 & 5.4 & 2.2 & 1.4 & 100 \\
\hline
\end{tabular}

Tablo 20: Ailenin Geçimini Sağlayan Erkek Olduğu İçin Kadının Çalışmasına Gerek Yoktur

Tablo 20'de görülen on ikinci önermeye kadın öğrencilerin yüzde 86.1’i kesinlikle katılmadığını, yüzde 12.3'ü katılmadığını belirtmiştir (toplam katılmayan yüzde 98.4). Erkek öğrencilerin yüzde 60’ kesinlikle katılmadığını, yüzde 25.2'i katılmadığını belirtmiştir (toplam katılmayan yüzde 85.2). Dolayısıyla kadın ve erkek öğrencilerin kadının çalışması konusunda eşitlikçi tutuma yakın oldukları gözlenmiştir. Bununla birlikte kamusal alanda ücret karşılığı çalışan kadınların oranı erkeklere göre oldukça düşüktür. Kadın genellikle ücretsiz ev işleri yapmakta ve çocuklarına bakmaktadır. TÜIK'in “İstatistiklerle Kadın 2018” verilerine göre 15 yaş ve üzeri işgücüne katılım oranı erkeklerde yüzde 72.5 , kadınlarda yüzde 33.6'dır. Serpil Sancar'ın da belirttiği gibi sanayileşme sonucunda ev ve işyeri iki farklı alan haline gelmiştir. Piyasanın ve hanenin içinde ise farklı cinsiyet düzenleri oluşmuştur. Bu düzen çerçevesinde ücretli emeği ile ailenin reisi erkek olmuştur (Sancar, 2009: 51). KONDA'nın (2019) 
araştırmasında ise toplumun yüzde 54'ü kadının çalışmak için kocasından izin alması gerektiğini onaylamaktadır. Bu çalışmada üniversite öğrencilerinin büyük oranı kadınların çalışmasını desteklemektedir. Öğrencilerin bu tutumu eşitlikçi rollerin gelişmesi yönünde önemli bir adım olarak değerlendirilebilir.

\begin{tabular}{|c|c|c|c|c|c|c|c|}
\hline \multirow{2}{*}{\multicolumn{2}{|c|}{ Önerme 13}} & \multicolumn{5}{|c|}{ Üniversite Eğitimi Erkekler İçin Daha Önemlidir } & \multirow[b]{2}{*}{ Toplam } \\
\hline & & $\begin{array}{l}\text { Kesinlikle } \\
\text { Katılmıyorum }\end{array}$ & Katılmıyorum & Kararsızım & Katılıyorum & $\begin{array}{l}\text { Kesinlikle } \\
\text { Katılıyorum }\end{array}$ & \\
\hline \multirow[b]{2}{*}{ Kadın } & Sayı & 97 & 17 & 4 & 1 & 2 & 121 \\
\hline & Yüzde & 80.2 & 14.0 & 3.3 & 0.8 & 1.7 & 100 \\
\hline \multirow[b]{2}{*}{ Erkek } & Sayı & 98 & 33 & 8 & 7 & 8 & 154 \\
\hline & Yüzde & 63.6 & 21.4 & 5.2 & 4.5 & 5.2 & 100 \\
\hline \multirow[b]{2}{*}{ Toplam } & Sayı & 195 & 50 & 12 & 8 & 10 & 275 \\
\hline & Yüzde & 70.9 & 18.2 & 4.4 & 2.9 & 3.6 & 100 \\
\hline
\end{tabular}

Tablo 21: Üniversite Eğitimi Erkekler İçin Daha Önemlidir

WEF'in 2020 yılına ait Küresel Toplumsal Cinsiyet Uçurumu Raporu, Türkiye'nin 153 ülke arasında eğitimde 113. sırada olduğunu göstermektedir. Bu durum, eğitimde fırsat eşitliği konusunda oldukça geride kaldığımızın önemli bir göstergesidir. Bu çalışmada ise hem kadın hem erkek öğrencilerin eğitimde fırsat eşitliği konusunda, eşitlikçi bir tutuma sahip oldukları tespit edilmiştir. "Üniversite eğitimi erkekler için daha önemlidir" önermesini bir kadın ve bir erkek öğrenci boş bırakmıştır. Önermeye kadın öğrencilerin yüzde 80.2'i kesinlikle katılmadığını, yüzde 14'ü katılmadığını belirtmiştir (toplam katılmayan yüzde 94.2). Erkek öğrencilerin yüzde 63.6'ı kesinlikle katılmadığını belirtirken yüzde 21.4'ü katılmadığını belirtmiştir (toplam katılmayan yüzde 85). Önermeye iki kadın öğrenci kesinlikle katıldığını, bir kadın öğrenci de katıldığını belirtmiştir. Üniversite eğitimi alan kadın öğrencilerin çok düşük oranda da olsa bu önermeye katılması ya da kararsız kalması oldukça düşündürücüdür. Eğitimde fırsat eşitliği için verilen mücadelelerin farkında olamamak ve destek vermemek kadın üniversite öğrencilerinin bu konuda yeterince bilinçli olmadıklarını göstermesi açısında önemlidir. TÜIKK verilerine göre ise kadınların yüzde 9.4'ü “Erkek çocuğun eğitimli 
olması kız çocuğun eğitimli olmasından her zaman daha iyidir" önermesini desteklemektedir (Türkiye İstatistik Kurumu, 2015).

\begin{tabular}{|l|l|l|l|l|l|l|l|}
\hline \multicolumn{2}{|c|}{ Önerme 14} & \multicolumn{6}{|c|}{ Aileler Erkek Çocuklarına Kız Çocuklarından Daha Fazla Harçlık Vermelidir } \\
& $\begin{array}{l}\text { Kesinlikle } \\
\text { Katımıyorum }\end{array}$ & Katılmıyorum & Kararsızım & Katılıyorum & $\begin{array}{l}\text { Kesinlikle } \\
\text { Katııyorum }\end{array}$ & Toplam \\
\hline \multirow{3}{*}{ Kadın } & Sayı & 111 & 6 & 2 & 0 & 2 & 121 \\
\cline { 2 - 8 } & Yüzde & 91.7 & 5.0 & 1.7 & 0.0 & 1.7 & 100 \\
\hline \multirow{3}{*}{ Erkek } & Sayı & 99 & 32 & 8 & 7 & 6 & 152 \\
\cline { 2 - 8 } & Yüzde & 65.1 & 21.1 & 5.3 & 4.6 & 3.9 & 100 \\
\hline \multirow{3}{*}{ Toplam } & Sayı & 210 & 38 & 10 & 7 & 8 & 273 \\
\cline { 2 - 8 } & Yüzde & 76.9 & 13.9 & 3.7 & 2.6 & 2.9 & 100 \\
\hline
\end{tabular}

Tablo 22: Aileler Erkek Çocuklarına Kız Çocuklarından Daha Fazla Harçıı Vermelidir

Harçlık konusundaki önermeye kadın öğrencilerin yüzde 91.7’i kesinlikle katılmadığını, yüzde 5’i katılmadığını belirtmiştir (toplam katılmayan yüzde 96.7). Erkek öğrencilerin yüzde 65.1'i kesinlikle katılmadığını belirtirken yüzde 21.1'i katılmadığını belirtmiştir (toplam katılmayan yüzde 86.2). Dolayısıyla hem kadın hem de erkek öğrencilerin yüksek oranda eşitlikçi tutumu benimsedikleri gözlenmiştir. Altıparmak'ın (2018) çalışmasında ise "Erkek çocukları ailede daha önemlidir" önermesine öğrencilerin yüzde 90. 6'sının katılmadığı, yüzde 9.4'ünün katıldığını saptanmıştır.

\begin{tabular}{|c|l|l|l|l|l|l|l|}
\hline \multirow{2}{*}{ Önerme 15} & \multicolumn{6}{|l|}{ Miras Paylaşımında Erkeklere Kadınlardan Daha Çok Pay Verilmelidir } \\
\cline { 3 - 8 } & $\begin{array}{l}\text { Kesinlikle } \\
\text { Katılmıyorum }\end{array}$ & Katılmıyorum & Kararsızım & Katılıyorum & $\begin{array}{l}\text { Kesinlikle } \\
\text { Katılıyorum }\end{array}$ & Toplam \\
\hline \multirow{3}{*}{ Kadın } & Sayı & 109 & 6 & 4 & 1 & 2 & 122 \\
\cline { 2 - 8 } & Yüzde & 89.3 & 4.9 & 3.3 & 0.8 & 1.6 & 100 \\
\hline \multirow{3}{*}{ Erkek } & Sayı & 103 & 30 & 6 & 6 & 9 & 154 \\
\cline { 2 - 8 } & Yüzde & 66.9 & 19.5 & 3.9 & 3.9 & 5.8 & 100 \\
\hline \multirow{3}{*}{ Toplam } & Sayı & 212 & 36 & 10 & 7 & 11 & 276 \\
\cline { 2 - 8 } & Yüzde & 76.8 & 13.0 & 3.6 & 2.5 & 4.0 & 100 \\
\hline
\end{tabular}

Tablo 23: Miras Paylaşımında Erkeklere Kadınlardan Daha Çok Pay Verilmelidir 
Kadınların miras paylaşımı ve mülk edinme konusunda dünya genelinde arka planda kaldıkları bilinmektedir. Bu araştırmaya katılan öğrenciler ise bu konuda eşitlikçi bir tutum sergilemişlerdir. Önermeyi bir erkek öğrenci boş bırakmıştır. Önermeye toplamda kadın öğrencilerin yüzde 94.2'i, erkek öğrencilerin yüzde 86.4'u katılmadığını belirtmiştir. Benzer şekilde Yılmaz ve arkadaşlarının (2009) çalışmasında da mirastan yalnızca erkek çocuklarının faydalanması yönündeki önermeye öğrencilerin büyük bir bölümü (Kadın yüzde 97.5, Erkek yüzde 90.1) katılmadıklarını ifade etmişlerdir. Kahraman ve arkadaşlarının (2015) yaptığı çalışmada ise "Mirastan sadece erkek çocuğun pay alması gerekir” önermesine öğrencilerin yüzde 8.9'u katılmıştır.

Bu çalışmanın sonucunda kadın ve erkek öğrencilerin orta düzeyde eşitlikçi tutumu benimsedikleri, kadın öğrencilerin erkek öğrencilere göre daha eşitlikçi olduğu saptanmıştır. Öğrenciler eşitlikçi tutuma yakın olmakla birlikte geleneksel anlayışın etkileri de varlığını devam ettirmektedir. Örneğin "Yuvayı dişi kuş yapar” önermesinde kadın ve erkek öğrencilerin yüksek oranda kararsız olmaları düşündürücüdür. Bu durum özellikle geleneksel ev içi rollerin aile yaşamında varlığını etkin bir şekilde devam ettiğini göstermektedir. Ayrıca kadınların evleninceye kadar babalarının sözünü dinlemeleri yönündeki önermeye kadın öğrenciler eşitlikçi bakış açısı ile yaklaşırken erkek öğrenciler kararsız bir tutum sergilemektedir. Bu durum akla, kadınlar evlendikten sonra da eşlerinin sözünü mü dinlemek zorunda kalacaklar sorusunu getirmektedir.

Öngen ve Aytaç'ın (2013) çalışmasında kadınların erkeklere göre, Karasu ve arkadaşlarının (2017) çalışmasında ise erkeklerin kadınlara göre daha eşitlikçi tutuma sahip oldukları tespit edilmiştir. Benzer şekilde Önder ve arkadaşlarının (2013) çalışmasında da erkek öğrencilerin kadınlara göre daha eşitlikçi oldukları saptanmıştır. $\mathrm{Bu}$ çalışmada ise öğrencilerin toplumsal cinsiyet eşitliği tutum ölçeği toplam puan ortalaması 36.57'dir. Bu sonuca göre, çalışmaya katılan öğrencilerin orta düzeyde eşitlikçi tutuma sahip oldukları ve kadın öğrencilerin erkek öğrencilere göre daha eşitlikçi oldukları tespit edilmiştir. Örneğin "Erkekler statüsü yüksek mesleklerde çalışmalıdır” önermesine kadın öğrencilerin toplamda yüzde 69.4'ü katılmazken, erkek öğrencilerin toplamda yüzde 50.9'u katılmamıştır. "Erkekler kadınlara göre daha mantıklıdır" önermesine kadınların toplamda yüzde 88.5’i katılmazken, erkeklerin toplamda yüzde 66.4'ü katılmamıştır. "Yuvayı dişi kuş yapar” önermesine kadınların 
toplamda yüzde 47.6'sı katılmazken, erkekleri toplamda yüzde 28.7'si katılmamıştır. "Kadının en önemli rolü evine özen göstermek ve ailesi için yemek yapmaktır" önermesine kadınların toplamda yüzde 85'i katılmazken, erkeklerin toplamda yüzde 65’i katılmamıştır. "Erkeklerin ev işlerini yapmasını önemserim” önermesine kadınların toplamda yüzde 86.8 'i katılırken, erkeklerin toplamda yüzde 59.1'i katılmıştır. "Kadınların en önemli görevi anneliktir” önermesine kadınların toplamda yüzde 61.5 katılmazken, erkeklerin toplamda yüzde 45.5'i katılmamıştır.

“Erkekler statüsü yüksek mesleklerde çalışmalıdır” önermesine kadınların yüzde 17.6 oranında katılması geleneksel toplumsal cinsiyet rollerin etkisini bir ölçüde devam ettirdiğini göstermektedir. "Yuvayı dişi kuş yapar” önermesine kadınların yüzde 26.2 oranında katılması ise geleneksel ev içi rolleri benimseyen kadınların oranını ve ataerkil ideolojinin bu konudaki yaygınlığını göstermesi açısından önemlidir. "Bir genç kız evlenene kadar babasının sözünü dinlemelidir” önermesine kadınların yüzde 9.2'sinin katılması ise erkeklerin denetimini altında yaşamaya rıza gösteren kadınların oranını göstermesi açısında önemli bir veridir. Bu denetim muhtemelen evlendikten sonra da eş tarafından devam ettirilecektir. "Erkekler ağlamaz" önermesine ise kadınların büyük bir oranı (yüzde 94.2) katılmamaktadır. Toplumumuzda duyguları belli etmemeyi simgeleyen bu önerme kadınlar tarafından kabul görmemektedir. Bununla birlikte "Erkekler statüsü yüksek mesleklerde çalışmalıdır" önermesine erkek öğrencilerin yüzde 32.7'si katıldığını belirtmiştir. Bir başka deyişle erkek öğrencilerin önemli bir kısmı çalışma yaşamında statüsü yüksek mesleklerde çalışmayı kendilerine uygun bulmaktadır. "Yuvayı dişi kuş yapar" önermesine erkeklerin yalnızca yüzde 28.7'sinin katılmaması erkeklerin ev içi roller söz konusu olduğunda ataerkil ideolojiyi desteklediklerini göstermektedir. "Bir genç kız evlenene kadar babasının sözünü dinlemelidir” önermesine erkeklerin yüzde 21.2'sinin katılması erkeğin kadın üzerinde oluşturmak istediği denetimin bir göstergesi olarak değerlendirilebilir. "Erkekler ağlamaz" önermesine ise erkeklerin önemli bir oranının (yüzde 81.1) katılmaması, duygularını belli etmekten yana olduklarını göstermektedir.

Bulgular çerçevesinde, erkeklerin kamusal alanla ilgili konularda daha eşitlikçi olmakla birlikte özel alanla ilgili konularda geleneksel toplumsal cinsiyet rollerini kabul etme oranlarının daha yüksek olduğu görülmektedir. Kadının eğitim almasını, dışarıda çalışmasını bir başka ifadeyle para kazanmasını desteklemekle birlikte ev içi 
geleneksel rolleri de devam ettirmesini istedikleri görülmektedir. Kadın yuvayı kurmalı, babasının sözünü dinlemeli, erkeğe itaat etmeli, yemek yapmalı, annelik yapmalı ve aynı zamanda dışarıda çalışmalıdır.

\section{Sonuç ve Öneriler}

Çalışmanın sonucunda elde edilen veriler, üniversite öğrencilerinin toplumsal cinsiyet eşitliğine ilişkin görüşlerini ortaya koyması ve üniversitelerin bu konu doğrultusunda vereceği eğitici etkinlikler açısından önem taşımaktadır. Elde edilen veriler genel olarak öğrencilerin orta düzeyde eşitlikçi tutuma sahip olduklarını ve geleneksel bakış açısının da varlığını devam ettirdiğini göstermiştir. Ayrıca kadın öğrencilerin cinsiyet eşitliği tutum puanları ve sıra ortalamaları dikkate alındığında erkek öğrencilere göre daha yüksek bulunmuştur. Bu nedenle kadın öğrenciler ile erkek öğrenciler arasındaki fark anlamlıdır $(p<0.05)$. Sınıflar arasındaki fark ise anlamlı bulunmamıştır. Öğrencilerin ölçek maddelerine verdiği yanıtlardan anlaşıldığı gibi kadın ve erkek öğrenciler üzerinde geleneksel normlar ve kültürel değerler etkisini sürdürmekle birlikte eşitlikçi yönde de değişimin olduğu gözlenmektedir.

Sonuç olarak toplumsal cinsiyet eşitliğinin sağlanabilmesi için öğrencilerin öncelikle geleneksel cinsiyetçi tutumlardan uzaklaşmaları gereği ortaya çıkmaktadır. Elde edilen veriler, toplumsal cinsiyet eşitliği konusundaki sıkıntıların gözler önüne serilmesi ve toplumda cinsiyet eşitliği farkındalığının oluşturulmasının önemini bir kez daha ortaya koymaktadır. Bu bağlamda öğrencilerin cinsiyet eşitliğine yönelik tutumlarının gelişmesi için eğitim kurumu olan üniversitelerin bu konu üzerinde hassasiyetle durması gerekmektedir. Üniversite eğitiminde öğrencilerin geleneksel tutumları benimsemeleri, çağdaş bireyler yetiştirmeyi amaçlayan üniversitelerin hedeflerini tam olarak hayata geçiremediklerini göstermektedir. Üniversiteler geleneksel toplumsal cinsiyet rollerine yönelik kalıp yargıları değiştirmeyi hedefleyerek öğrencilerini eşitlikçi cinsiyet rollerine yönlendirmelidir. Bu nedenle üniversitelerde toplumsal cinsiyet eşitliğine yönelik derslere ağırlıklı olarak yer verilmesi büyük önem arz etmektedir.

Sağlık Bakanlığı çalışanlarına uygulanan Toplumsal Cinsiyet Eşitliği Tutum Ölçeği'nin ön-test ortalaması 7.71, son-test ortalaması ise 12.56 olarak tespit edilmiştir. Ön-test sonrası verilen eğitim, çalışanların Toplumsal Cinsiyet Eşitliği Tutumları'nda 
yüzde 50'den fazla yükselmeye neden olmuştur (2016: 315). Bu sonuç eşitlikçi bakış açısının gelişmesinde eğitimin önemini göstermesi açısından önemlidir. Benzer şekilde Uzun ve ark. tarafından gerçekleştirilen çalışmada da eğitimin katılımcıların toplumsal cinsiyet algılarının ortalamalarını ve toplumsal cinsiyet rollerine ilişkin tutumlarını önemli oranda artırdığı tespit edilmiştir. Eğitim sonrasında özellikle erkek katılımcıların ortalamalarının kadınlara göre daha fazla yükseldiği saptanmıştır (Uzun ve ark., 2017).

Eğitimin toplumsal cinsiyet eşitliğine ilişkin tutum üzerindeki etkisini gösteren bu veriler de, üniversite eğitiminin her aşamasında "Toplumsal Cinsiyet Eşitliği” dersleri ile farkındalık yaratmanın önemini göstermektedir. Bu bağlamda öğrencilerin toplumsal cinsiyet rollerine ilişkin görüşlerinin tespit edilmesi ve bu konuda öğrencilerin bilinçlendirilmesi, geleneksel bakış açısı yerine gençlerin toplumsal cinsiyet rollerine ilişkin görüşlerini eşitlikçi bir bakış açısıyla güçlendirmek büyük önem taşımaktadır. Ayrıca farkındalık oluşturmak için düzenlenecek panel ve sempozyum gibi etkinlikler aracılığı ile öğrencilerle bilgi paylaşımı artırılmalıdır. Bununla birlikte öğrenciler arasındaki tutum farklılıklarını saptayabilmek amacıyla üniversitelerin çeşitli bölümlerinde benzer çalışmalar devam ettirilmelidir. Daha güzel bir dünya eşit koşullarda sağlanacaktır. 


\section{Kaynakça}

Agarwal, Bina (1994). A Field of One's Own: Gender and Land Rights in South Asia. Cambridge: Cambridge University Press.

Aile, Çalışma ve Sosyal Hizmetler Bakanlığı Kadının Statüsü Genel Müdürlüğü (2020).

Türkiye'de Kadın. www.ailevecalisma.gov.tr/media/44013/02-03-2020-tr-dekadin-donusturuldu.pdf Erişim tarihi: 30.04.2020

Aile ve Sosyal Politikalar Bakanlığı (2016). Aile lç̧i Şiddetle Mücadele Projesi / Sağlık Çalışanları El Kitabı. Ankara.

Akın, Ayşe (2007). "Toplumsal Cinsiyet Ayrımcılığı ve Sağlık." Toplum Hekimliği Bülteni, 26 (2):1-10.

Althusser, Louis (2000). Ideoloji ve Devletin Ídeolojik Aygıtları. Çev., Yusuf Alp, Mahmut Özışık. İstanbul: İletişim Yayınları.

Altıparmak, İpek Beyza (2018). "Toplumsal Cinsiyet Üzerine Sosyolojik Bir Araştırma: Kaynakları ve Mücadele Alanlarına Yönelik Öneriler.” Turkish Studies Social Sciences, 13(18): 179-194.

Balkır, Z. Gönül (2012). "Toplumsal Cinsiyet ve Toplumsal Cinsiyet Ayrımcılığı." TÜBAKKOM: 1.Kadın Avukatlar Kurultayı. Aydın Barosu Kadın Hukuku Komisyonu (der.) içinde. Ankara: Türkiye Barolar Birliği Yayınları. 68-94.

Başol, Gülşah (2013). "Paremetrik Testlerin Sayıltıları." www.slideshare.net/gbasol/blm5sunu Erişim tarihi: 29.12.2020

Baykal, Serçin (1991). "Üniversite Öğrencilerinin Cinsiyet Rolleri ile İlgili Kalıp Yargılarının Bazı Değişkenler Açısından İncelenmesi." Psikolojik Danışma ve Rehberlik Dergisi, 1(2): 66-75.

Butler, Judith (2019). Cinsiyet Belası: Feminizm ve Kimliğin Alt Üst Edilmesi. Çev., Başak Ertür. İstanbul: Metis Yayınları.

Cangöz, İncilay (2013). "Iletişim Fakültesi Öğrencilerinin Toplumsal Cinsiyet Farkındalığı ve Cinsiyetçi Şiddetle İlgili Görüşleri.” Illeti-ş-im, 19: 41-64.

Connell, Robert William (1998). Toplumsal Cinsiyet ve Iktidar. Çev., Cem Soydemir. İstanbul: Ayrıntı Yayınları. 
Cumhuriyet (2020). "Elektrik-Elektronik Sektöründe Çalışma Koşulları ve Toplumsal Cinsiyet Rollerinin Kadın İşçiler Üzerindeki Etkileri: İşyeri Vaka Analizi.” www.cumhuriyet.com.tr/haber/toplumsal-cinsiyet-rolleri-kadin-iscileri-hastaediyor-1802078 Erişim tarihi: 28.12.2020

Ecevit, Yıldız (2011). "Toplumsal Cinsiyet Sosyolojisine Başlangıç." Toplumsal Cinsiyet Sosyolojisi. Yıldız Ecevit ve Nadide Karkıner (der.) içinde. Eskişehir: AÖF Yayını. 3-30.

Elgün, Aslı ve Mine Alemdar (2017). “Üniversite Öğrencilerinin Toplumsal Cinsiyet Rolleri Tutumlarına Yönelik Bir Araştırma: Ege Üniversitesi İletişim Fakültesi Örneği." International Journal of Social Sciences and Educational Research, 3(3): 1054-1067.

Demir, Ergül (2017). "İstatistik Ders Notları." www.academia.edu/30931820/Istatistik_Ders_Notlarim_E_Demir_2017_pdf Erişim tarihi: 19.01.2021

Esen, Siyez vd. (2017). "Üniversite Öğrencilerinde Toplumsal Cinsiyet Algısının Toplumsal Cinsiyet Rolü ve Cinsiyet Değişkenlerine Göre İncelenmesi.” EUluslararası Eğitim Araştırmaların Dergisi, 8 (1): 46-63.

Esmer, Yılmaz (2012). "Türkiye Değerler Atlası 2012." www.slideshare.net/syurdam/atlas-sunum-2-10-2012-2

Erişim tarihi: 29.12.2020

Giddens, Anthony (2008). Sosyoloji. Çev., Hüseyin Özel vd. İstanbul: Kırmızı Yayınları.

Yağan Güder, Sevcan ve Tülin Güler Yıldız (2016). "Okul Öncesi Dönemdeki Çocukların Toplumsal Cinsiyet Algılarında Aileni Rolü." Hacettepe Üniversitesi Eğitim Fakültesi Dergisi, 31(2): 424-446.

Hacettepe Üniversitesi Nüfus Etütleri Enstitüsü (2019). 2018 Türkiye Nüfus ve Sağlık Araştırması.http://www.hips.hacettepe.edu.tr/tnsa2018/rapor/TNSA2018_ana_ Rapor.pdf Erişim tarihi: 05.11.2019

Hacettepe Üniversitesi Nüfus Etütleri Enstitüsü (2004). Türkiye Nüfus ve Sağlık Araştırması. http://www.hips.hacettepe.edu.tr/pdf/TNSA2003-AnaRapor.pdf Erişim tarihi: 26.04.2020 
Jersild, Arthur T. (1978). Gençlik Psikolojisi. Çev., İbrahim N. Özgür. İstanbul: Takıoğlu Matbaacılık.

Kahraman, Tunçdemir vd. (2015). "Üniversite Öğrencilerinin Toplumsal Cinsiyet Algıları." Sobider / Sosyal Bilimler Dergisi, 2 (4):304-322.

Kandiyoti, Deniz (1997). Cariyeler Bacılar Yurttaşlar Kimlikler ve Toplumsal Dönüşümler. Çev., Aksu Bora, Fevziye Sayılan, Şirin Tekeli, Hüseyin Tapınç, Ferhunde Özbay. İstanbul: Metis Yayınları.

Kaos GL (2020). “LGBTi̇+ Hakları Alanında Çeviri Sözlüğü.” Deniz Gedizlioğlu (Haz.). www.kaosgldernegi.org/images/library/cevirisozlugu2020.pdf Erişim tarihi: 24.12.2020

Karasar, Niyazi (1995). Bilimsel Araştırma Yöntemi. Ankara: 3A Araştırma, Eğitim Danışmanlık Ltd.

Karasu, Göllüce vd. (2017). “Üniversite Öğrencilerinin Toplumsal Cinsiyet Rollerine İlişkin Tutumları.” Sdü Sağlık Bilimleri Dergisi, 8(1): 21-27.

KONDA (2019). Türkiye'de Toplumsal Cinsiyet Raporu, Hayat Tarzları 2018 Araştırması.www.konda.com.tr/wpcontent/uploads/2019/11/KONDA_Top lumsalCinsiyetRaporu.pdf. Erişim tarihi:12.03.2020

Kongar, Emre (2019). “Kör Cehaletin Doymak Bilmez Açlığı.” Cumhuriyet,12.12.2019. https://www.cumhuriyet.com.tr/yazarlar/emre-kongar/kor-cehaletin-doymakbilmez-acligi-1707667 Erişim Tarihi: 13.01.2020.

Marshall, Gordon (1999). Sosyoloji Sözlüğü. Çev., Osman Akınhay ve Derya Kömürcü. Ankara: Bilim ve Sanat Yayınları.

Minibaş, Türkel (1998). “Türkiye'nin Kalkınma Sürecinde Kadın İşgücü.” Aydınlanmanın Kadınları. Necla Arat (der.) içinde. İstanbul: Cumhuriyet Kitapları.

Morris, Charles G. (2002). Psikolojiyi Anlamak. Çev., H. Belgin Ayvaşık ve Melike Sayıl. Ankara: Türk Psikologlar Derneği Yayınları No: 23. 
Önder, Yalçın vd. (2013). "Sağlık Kurumları Yöneticiliği Bölümü Öğrencilerinin Toplumsal Cinsiyet Rollerine İlişkin Tutumları.” Ankara Sağlık Bilimleri Dergisi, $2(1): 55-78$.

Öngen, Burcu ve Serpil Aytaç (2013). "Üniversite Öğrencilerinin Toplumsal Cinsiyet Rollerine İlişkin Tutumları ve Yaşam Değerleri İlişkisi.” Sosyoloji Konferansları, 48(2): 1-18.

Örmeci, Ozan (2016). "Dünya Değerler Araştırması 2010-2014 Türkiye Verileri Analizi." Uluslararası Politika Akademisi. http://politikaakademisi.org/2016/12/27/dunya-degerler-arastirmasi2010-2014-turkiye-verileri-analizi/ Erişim tarihi:14.12.2019

Pınar, Taşkın vd. (2008). "Başkent Üniversitesi Öğrenci Yurdunda Kalan Gençlerin Toplumsal Cinsiyet Rol Kalıplarına İlişkin Tutumları." Hacettepe Üniversitesi Sağlık Bilimleri Fakültesi Hemşirelik Dergisi, 15(1): 47-57.

Pilcher, Jane (2017). "Toplumsal Cinsiyet ve Cinsiyet Eşitsizlikleri Üzerine Açıklamalar." Sosyoloji Başlangıç Okumaları. A. Giddens (der.) içinde. Çev., Günseli Altaylar. İstanbul: Say Yayınları.

Sancar, Serpil (2009). Erkeklik: Imkansız Iktidar. İstanbul: Metis Yayınları.

Scott, Joan W. (2010). "Toplumsal Cinsiyet: Faydalı Bir Tarihsel Analiz Kategorisi.” Çev. Derya Demirler, Fahriye Dinçer. Feminist Yaklaşımlar, 12: 112-138. http://www.feministyaklasimlar.org/wp-content/uploads/2013/05/12-

9.TOPLUMSAL-CINSIYET.pdf Erişim tarihi: 06.11.2010

Seven, Nur (2019). "Üniversite Öğrencilerinin Toplumsal Cinsiyet Rollerine İlişkin Tutumları." Pesa Uluslararası Sosyal Araştırmalar Dergisi, 5 (2):134-149.

Sever, Merin (2014). "Queer Teori Ekseninde LGBTI Hareketi ve Feminizm.” Birikim, Sayı: 308: 42-47.

Şemin, Refia (1973). Gençlerimizin Psiko-Pedogojik Problemleri. İstanbul: İstanbul Üniversitesi Edebiyat Fakültesi Yayınları No:108.

Şiddetten Ölen Kadınlar İçin Dijital Anıt (2019). www.anitsayac.com/?year=2019 
Türkiye İstatistik Kurumu (2019a). “istatistiklerle Kadın 2018.” https://data.tuik.gov.tr/Bulten/Index?p=Istatistiklerle-Kadin-2018-30707 Erişim tarihi: 27.06 .2020

Türkiye İstatistik Kurumu (2019b). “i̇şgücü İstatistikleri Ağustos 2019.” www.data.tuik.gov.tr/Bulten/Index?p=Isgucu-Istatistikleri-Agustos-2019-30692 Erişim tarihi: 20.06.2020

Türkiye İstatistik Kurumu (2019c). '’̧̇şgücü İstatistikleri Temmuz 2019-İşteki Durum ve Ekonomik Faaliyetlere Göre İstihdam Edilenler." https://data.tuik.gov.tr/Bulten/Index?p=Isgucu-Istatistikleri-Temmuz-201930687 Erişim tarihi: 25.04.2020

Türkiye İstatistik Kurumu (2018). "Istatistiklerle Kadın 2017." https://data.tuik.gov.tr/Bulten/Index?p=Istatistiklerle-Kadin-2017-27594 Erişim tarihi: 27.08 .2020

Türkiye İstatistik Kurumu (2017). "Istatistiklerle Kadın 2016." https://data.tuik.gov.tr/Bulten/Index?p=Istatistiklerle-Kadin-2016-24643 Erişim tarihi: 27.08 .2020

Türkiye İstatistik Kurumu (2015). "Istatistiklerle Kadın 2014." https://data.tuik.gov.tr/Bulten/Index?p=Istatistiklerle-Kadin-2014-18619 Erişim tarihi: 29.12 .2020

Uzun, Erdem vd. (2017). "Toplumsal Cinsiyet Algısı ve Toplumsal Cinsiyet Rollerine Eğitimin Etkisi: Deneysel Bir Çalışma." Journal of Human Sciences, 14(1):678693.

Vefikuluçay, Zeyneloğlu vd. (2007). "Kafkas Üniversitesi Son Sınıf Öğrencilerinin Toplumsal Cinsiyet Rollerine İlişkin Bakış Açıları." Hacettepe Üniversitesi Hemşirelik Yüksekokul Dergisi, 14(2): 26-38.

Word Economic Forum (2018). Global Gender Gap Report 2018. www3.weforum.org/docs/WEF_GGGR_2018.pdf Erişim tarihi: 12.04.2020

Word Economic Forum (2020). Global Gender Gap Report 2020. www3.weforum.org /docs / WEF_GGGR_2020.pdf Erişim tarihi: 15.04.2020 
Yılmaz, Zeyneloğlu vd. (2009). "Üniversite Öğrencilerinin Toplumsal Cinsiyet Rollerine İlişkin Görüşleri.” Uluslararası Insan Bilimleri Dergisi, 6(1):775-792.

Yüksel-Kaptanoğlu, İlknur vd. (2015). Türkiye'de Kadına Yönelik Aile Içi Şiddet Araştırması.TC Aile ve Sosyal Politikalar Bakanlığı, Hacettepe Üniversitesi Nüfus Etütleri Enstitüsü. www.hips.hacettepe.edu.tr/siddet2014/rapor/KKSATRAnaRaporKitap26Mart.pdf Erişim tarihi: 14.12.2020

Zara, Ayten ve Burçak Özdemir (2013). "Cinsiyet Rolleri." Kadınların Yaşamı ve Kadın Ruh Sağlığı. Şahika Yüksel, Leyla Gülseren ve Ayşe Devrim (der.) içinde. Ankara: Türkiye Psikiyatri Derneği Yayınları. 